\title{
CONSTRUCTIVE CONTEMPT: A POST-MORTEM
}

RAOUL BERGER*

$7 \mathrm{HE}$ expansion of the Fourteenth Amendment in contravention of historic conceptions has become so commonplace ${ }^{x}$ that it is doubtless naive to confess astonishment at the latest extension of due process. One hundred and fifty years after the adoption of the Bill of Rights we learn in Bridges v. California ${ }^{2}$ that the long-recognized summary power of courts over contemptuous publications was curtailed by the First Amendment and later by the Fourteenth. It is remarkable certainly that Mr. Justice Black, who not long ago amazed the profession by urging that corporations are historically outside the protection now afforded them by due process, ${ }^{3}$ should be the instrument of this extension. And it is little less remarkable to find Mr. Justice Frankfurter dissenting, ${ }^{4}$ in the light of his biting repudiation of the power in I924. ${ }^{5}$ His opinion now posits that the summary power over contemptuous publications, brushed aside as historically "dubious" by Mr. Justice Black, ${ }^{6}$ is in fact "deeply rooted" in the common law, " and further, that the "power to punish for contempt is not a censorship in advance but a punishment for past conduct and, as such, like prosecution for a criminal libel, is not offensive either to the First or to the Fourteenth Amendments. . . ."8 It is this position which is to be elaborated in this article.

If it is true, however, that the Fourteenth Amendment does not cut across the contempt power, then it seems to follow that a summary commitment for contemptuous publications, absent other considerations of

* Member of the District of Columbia and Illinois bars. The writer is indebted to Messrs. Irwin Langbein and Malcolm Mason for criticism.

I Cohen, Constitutional and Natural Rights in 5789 and Since, I Nat'l Lawyer's Guild Q. 92, 93 (I938); Corwin, Twilight of the Supreme Court 78, 79, 91 (I934). For additional citations see Read, The Constitution Reconsidered 23r n. 26 (1938).

23 I4 U.S. 252 (I94I).

3 Connecticut Gen'l Life Ins. Co. v. Johnson, 303 U.S. 77, 85-90 (x937). We are startled because a Justice cries out "like the child in the story that the king is after all naked," that the Court has woven "imaginary garments for the nakedness of corporate power." Lerner, Ideas Are Weapons 264 (1939).

4 Stone, C.J., and Roberts and Byrnes, J.J., concurred in the dissent.

5 Frankfurter and Landis, Power of Congress over Procedure in Criminal Contempts in "Inferior" Federal Courts-A Study in Separation of Powers, 37 Harv. L. Rev. IoIo (I924); cf. page 605 infra; Radin, Freedom of Speech and Contempt of Court, 36 IIl. I. Rev. 599, 608 (I942).

${ }^{6}$ Bridges v. California, 3I4 U.S. 252, 264 (I94I). $\quad 7$ Ibid., at $284 . \quad{ }^{8}$ Ibid., at 290. 
due process, affords no grounds for reversal by the Supreme Court. 9 But Mr. Justice Frankfurter does not press his logic so far, since he agrees with the majority that two of the contempt judgments in companion cases must be reversed, thereby concurring in the view that the Fourteenth Amendment limits the power. ${ }^{\times 0}$ His real difference with the majority appears to arise out of the majority's application of the "clear and present danger" formula to the remaining two cases.. Br Bridges, a labor leader; had virtually threatened to call a strike if a then pending decision was enforced. ${ }^{\mathrm{I2}}$ In a companion case, the Los Angeles Times had editorially advised the judge that he would "make a serious mistake" to grant probation rather than a severe sentence to certain labor "gorillas." "r3 The refusal of the majority to find a "clear and present danger" to, or even a "reasonable tendency" to obstruct, impartial arbitrament in these circumstances practically puts it beyond the power of courts to deal with utterances which have hitherto been deemed to constitute an obstruction to the administration of justice.

This was the rock upon which the Supreme Court split, for the minority felt that "trial by newspaper" imperils the fundamental right to an impartial trial. ${ }^{.4}$ But the reality of this peril was questioned when Mr. Justice Holmes, dissenting in a case that involved threats of a streetcar riders' strike published to deter the judge from entering an order invalidating a fare ordinance, declared that " $a$ judge of the United States is expected to be a man of ordinary firmness of character, and I find it impossible to believe that such a judge could have found in anything that was printed even a tendency to prevent his performing his sworn duty."' ${ }^{15}$ The

- Cf. Patterson v. Colorado, 205 U.S. 454, 462, 463 (1907); Bridges v. California, 3I4 U.S. 252,284 (I94r).

10 Ibid., at 297-98; cf. ibid., at 274-75.

12 Ibid., at 276 n. 20.

23 Ibid., at 295-303.

${ }_{3}$ Ibid., at 272 n. 17.

24 Ibid., at $283-84$. The English practice, cited by the minority, ibid., at 294 , goes far beyond the bounds of actual threats addressed to a court. It embraces pre-trial discussion which may influence potential jurors, publications which may discourage parties or witnesses from coming forward, and, in short, extends to all instances which threaten to obstruct the course of impartial justice. See Goodhart, Newspapers and Contempt of Court in English Law, 48 Harv. L. Rev. 885, 888-90, 895 (I935); Sullivan, Contempts by Publication 48 et seq. (2d ed. I940). As will appear, there is no logical or historical warrant for curtailing such contempts while singling out "intimidation" of the court for favored treatment.

${ }^{25}$ Toledo Newspaper Co. v. United States, 247 U.S. 402, 424 (IgI8). Mr. Justice Holmes pointed out that the alleged contempt there involved consisted of printed statements approving "a widespread public intent to board the cars and refuse to pay more than three cents [the new fare promulgated by city ordinance] even if the judge condemned the ordinance....." This was of course incitement to disobey a possible court order, and the call for impeachment of the judge was no less "obstructive." 
realistic analysis of $\mathrm{Mr}$. Justice Black follows this sensible tradition ${ }^{16}$ and places free speech beyond the mercies of an offended judge. It requires no extensive reading of contempt cases to awaken distrust of the role played by the personal feeling of the judge. ${ }^{17}$ And it cannot be gainsaid that there has been recurring resentment at the use of the contempt power to curb criticism of the bench. Since frequent legislative efforts to curb the power have been rendered abortive by judicial construction, ${ }^{x 8}$ the Bridges decision supplies an eminently practical if Draconian solution, unexpectedly cutting down jury trial for contemptuous publications as well. ${ }^{x 9}$

But, it is the thesis of this article, the evidence that the First Amendment was not designed to curtail the established summary power appears to be so conclusive that the larger question emerges: can the liberals, after steadily criticizing the tendency of the pre-"reconstructed"20 court to read

${ }_{16}$ "With an eye on the realities of the situation, we cannot assume that Judge Schmidt was unaware of the possibility of a strike as a consequence of his decision. If he was not intimidated by the facts themselves, we do not believe that the most explicit statement of them could have sidetracked the course of justice." Bridges v. California, 3I4 U.S. 252, 278 (I94I). The "editorial . . . . did no more than threaten future adverse criticism which'was reasonably to be expected anyway [in view of the Times' well-known policy on labor controversies] in the event of a lenient disposition of the pending case." Ibid., at 273. The masterly espousal of the majority position on this issue by Radin, op. cit. supra note 5 , renders further comment superfluous. Here it need only be pointed out that if, as the minority insists, the criterion is to be the threat to impartial decision, Bridges v. California, 3I4 U.S. 252, 303-4 (I94I), why did it sanction an editorial expressing "exulting approval of the verdict" before sentence was imposed in a companion case? Tbid., at 297. For "friendly backing is obviously more likely than hostile aspersion to influence a judge. It is easier to close a mind than to open one. To fortify a judge in his prepossession tends to close his mind and so impede his proper discharge of judicial functions." Nelles and King, Contempt by Publication in the United States, 28 Col. L. Rev. 40 I, 547 n. 92 (1928); cf. State v. New Mexican Printing Co., 25 N.M. I02, III-I4, I77 Pac. 751, 755 (IgI8). An acute analysis of the whole question of "trial by publication" in relation to summary procedure is found in Nelles and King, op. cit. supra, at 548 et seq.

${ }_{77}$ The offended judge did not sit in the Bridges case, but that is the exception rather than the rule. The cases are discussed in Nelles and King, op. cit. supra note I6, at 545-47. See Ex parte Nelson, 251 Mo. 63, r57 S.W. 794 (19r3) (trial judge had made up his mind and written his opinion before the contempt hearing); United States ex rel. Guaranty Trust Co. v. Gehr, II6 Fed. 520 (C.C. W.Va. I902); note 229 infra.

${ }_{18}$ Toledo Newspaper Co. v. United States, 247 U.S. 402 (rgr8); State v. Morrill, r6 Ark. 384 (1855); Bridges v. Superior Court, 14 Cal. (2d) 464 , 94 P. (2d) 983 (I939). The cases are collected in Nelles and King, op. cit. supra note I6, at 554-62. The thorny path to amendment is ordinarily cited by those who know that it is generally insuperable.

I9 The Bridges case does not rest on the procedural deprival of due process but upon the infringement of free speech. Curiously enough, Mr. Justice Frankfurter directs attention to the statutes permitting indictment for such contempts but does not advert to the effect of the decision on jury trial. The majority opinion also fails to note the point. Bridges v. California, 314 U.S. 252, 305 (194I); cf. Radin, op. cit. supra note 5, at 609.

${ }^{20}$ See Mr. Justice Frankfurter's concurring opinion in Graves v. New York ex rel. O'Keefe, 306 U.S. 466,487 (1939). 
laissez-faire into the Constitution, ${ }^{2 x}$ afford to sanctify by their own example an interpretive approach which for a generation was employed to block social legislation and may once again be turned against themselves?

That approach, it is trite to remark, purported to give effect to inexorable constitutional mandates, while in fact the prejudices of the justices had become the Procrustean test of overdue social adjustment. ${ }^{22}$ Let it be admitted that at the outset the identification by conservative justices of individualistic preferences with constitutional dogma probably reflected the prevailing climate of opinion. ${ }^{23}$ But the present Court is too sophisticated to make an analogous identification. Notwithstanding, the liberal justices employ a discredited technique in the Bridges case in order to read their predilections into the Constitution. To peel the historical veneer from this process we must trace the growth of the contempt power and examine the guarantee of free speech and press against a setting contemporary with its adoption. An adequate description of the present status of the contempt power necessitates discussion of Nye v. United States, ${ }^{24}$ wherein the Supreme Court recently held that the Act of I83I limited the exercise of summary power by federal courts over all out-ofcourt contempts. Thus fell Toledo Nerospaper Co. v. United States; ${ }^{25}$ and the startling echoes of that fall yield only to the reverberations of the Bridges case.

\section{COMMON IAW ORIGINS}

After reviewing modern studies concerned with published contempts, a recent dissenter concluded that "the courts have built a structure of judicial reasoning upon the sands of precedents which do not exist." 26 This view reflects the historical approach taken in 1924 by Frankfurter and Landis, ${ }^{27}$ it rests ultimately on the exhaustive labors of Sir John Charles Fox; ${ }^{28}$ and apparently it is now the view of the Supreme Court. ${ }^{29}$ The

${ }^{2 x}$ The classic criticisms are those of Mr. Justice Holmes, dissenting in Lochner v. New York, I98 U.S. 45, 74-76 (I905), and in Baldwin v. Missouri, 28I U.S. 586, 595-96 (1930).

${ }^{22}$ Hamilton and Braden were, it appears, unduly optimistic in stating that recent changes strike at "a dualism between word and deed, by which the Court could act and yet deny the consequences of its own decision. It makes it impossible any longer for the majority of the bench to pretend not to do that in which they were busily engaged." Hamilton and Braden, The Special Competence of the Supreme Court, 50 Yale L.J. r3I9, I329-30 (I94I).

23 Note $25^{8}$ infra.

${ }^{24} 313$ U.S. 33 (I94r).

25247 U.S. 402 (19I8).

${ }^{26}$ Edmonds, J., dissenting in Bridges v. Superior Court, $\mathrm{r}_{4}$ Cal. (2d) 464, 495, 94 P. (2d) 983,999 (1939).

${ }^{27}$ Frankfurter and Landis, op. cit. supra note 5 ; see page 602 supra.

${ }^{28}$ His works are hereinafter cited.

${ }^{29}$ Bridges v. California, 3I4 U.S. 252, 264 (I94I). 
Frankfurter and Landis article furnishes a convenient summary of the animadversions upon the origins of the power strewn throughout the pages of Fox's numerous studies. Roughly, that article states that except for contempts by officers of the court, or in the actual view of the court, trial by jury was had down to the eighteenth century, and that the Star Chamber asserted a summary power over contempts until it was abolished in $\mathrm{r} 64 \mathrm{I}$. To continue in the words of the article:

But the atmosphere of corrupt and arbitrary practices which it had generated partly survived. Gradually there appear traces of infection in the King's Bench which succeeded to the jurisdiction of the Star Chamber. The odious commitments by the Restoration Parliament . . . reinforced the practice of arbitrary procedure. . . . This infusion of Star Chamber methods on the common law side appears most vigorously in the undelivered judgment of Wilmot, J., in Rex v. Almon. .... It has bedevilled the law of contempt both in England and in this country ever since. .... Wilmot's history is fiction. .....30

Thus one gains the impression that this branch of the contempt power is of illegitimate origin, and that, as regards the law courts, it sprang fullarmed from the brain of Mr. Justice, later Chief Justice, Wilmot in I765. Fox, it is to be noted, sought chiefly to demonstrate that Wilmot's sweeping dictum, basing the summary power over contemptuous publications on immemorial usage, ${ }^{3 \mathrm{x}}$ was unfounded..$^{32}$ In this he was unquestionably successful. The very cases collected by Fox, however, disclose that the power was completely established in the early eighteenth century. ${ }^{33}$ So much Mr. Justice Frankfurter now postulates in the Bridges case. ${ }^{34}$ It is the thesis of this section that the power did not spring into being in an eighteenth century void, but that it began long before to develop logically from the comprehensive summary jurisdiction of medieval courts. Not that the argument need for present purposes go so far. Given an established and familiar eighteenth century power at the adoption of the Constitution,

$3^{\circ}$ Frankfurter and Landis, op. cit. supra note 5, at 1045-47 (the quotation is telescoped). Radin, op. cit. supra note 5, at 609, commenting on the Bridges case, said "It was not assumed, until the posthumously published [ $\mathrm{r} 8 \mathrm{O} 2]$ judgment in Almon's case, that it [contemptuous publications] could be dealt with summarily. ...."

${ }^{3 x}$ Rex v. Almon, Wilm. 243, 254 (K.B. I765).

${ }_{32}$ "It remains to be determined by an appeal to history whether or not the doctrine is supported by immemorial usage. If it should prove that contempts out of court committed by strangers were before the seventeenth century punished by the common law courts [as distinguished from Chancery], only upon conviction after trial in the ordinary course of law, it follows that the present practice in such cases, though established by a long line of decisions, is based on a misapprehension." Fox, The History of Contempt of Court 43 (rg29); see ibid., at $3,4,15,24,26,33,49,98$, II2.

. 33 Page 6r2 infra. 34 Bridges v. California, 3r4 U.S. 252, 284-85 (I94I). 
the case for the devolution of the power upon the federal courts stands no worse at least than that of familiar equity doctrines of no less recent origin. ${ }^{35}$ But it cannot be amiss in considering the constitutional issue raised by the Bridges case to dispel the bias that must arise from the current impression that the power is a product of gross usurpation. This task is the more essential because the dissent of Mr. Justice Frankfurter is - likely to perpetuate an historical error with respect to the origins of the power, and as he has since remarked, "legal history still has its claims." 36

The summary power extended from earliest times to disobedience of judicial writs or orders, ${ }^{37}$ to all contempts by judicial officers, i.e., jurors, attorneys, and the like, ${ }^{38}$ and to contempts committed in the actual view of the court. ${ }^{39}$ Contempts committed by strangers out of court, or in the presence but not in the actual view of the court, were tried by jury. Parties were "more strictly amenable than strangers" to the summary jurisdiction..$^{\circ}$ Many, perhaps most, cases of contempts in the actual view of the court were tried by jury.4I And there are cases in which attorneys

${ }^{35}{ }_{3}$ Bl. Comm. * 53 ; I Holdsworth, History of English Law 454, 465 (3d ed. I922); see In re Hallett's Estate, $x_{3}$ Ch.D. 696, 7 ro (C.A. 1879 ).

${ }^{36}$ Federal Power Com'n v. Natural Gas Pipeline Co., 62 S.Ct. 736, 754 (r942). Mr. Justice Frankfurter in the Bridges case rejected that portion of summary jurisdiction known as "scandalizing the court," i.e., bringing it into disrepute, as an "abuse" whereby "some English judges extended their authority," saying that "such foolishness has long since been disavowed in England and has never found lodgment here." Bridges v. California, 3r4 U.S. 252, 287 (I94I).

${ }^{37} 3$ Holdsworth, op. cit. supra note 35 , at 39 ; Fox, op. cit. supra note 32 , at $x 8$. Such contempts may appear irrelevant because "civil" rather than "criminal." But Sayles justly remarks that "so sharp a distinction is difficult to uphold in the thirteenth and fourteenth century." 3 Select Cases in the Court of Kings Bench (Edw. I), 58 Seld. Soc. Ixxvii (r939).

${ }^{38}$ Fox, op. cit. supra note 32 , at I56, I57; Fox, The Summary Process to Punish Contempt, 25 Law Q. Rev. 238, 244 (Igog); Fox, The Nature of Contempt of Court, 37 Law Q. Rev. rgr, $\mathrm{I} 92(\mathrm{rg} 2 \mathrm{I})$.

39 Fox, op. cit. supra note 32 , at ix, 50-52, II6. Sayles accepts the summary punishment of disobedience to process and of court officers, Sayles, op. cit. supra note 37 , at lxxvii, lxxix, but questions whether the cases of contempt in the view of the court represent summary punishment rather than commitment to await punishment, ibid., at $\mathrm{lxxx}$, Lxxxi. Sayles does not explain why flagrant in-court contempts should be remitted to jury trial while often innocuous out-of-court disobedience to court orders would be punished summarily. Fox's citations are persuasive, and his position has been adopted by Holdsworth, op. cit. supra note 35, at 392 . This difference of opinion does not affect the present thesis, because the power over contemptuous publications derives from disobedience to court orders, conceded by Sayles to be a branch of the summary jurisdiction.

${ }^{40}$ Fox, op. cit. supra note 32, at I 6 ; cf. Plucknett, Review of Fox, The History of Contempt of Court, 4 r Harv. L. Rev. 270 (I928).

${ }_{42}$ Fox, The King v. Almon, 24 Law Q. Rev. 266, 267 (I908); note to Davis's Case, 2 Dyer * $188 b, 73$ Eng. Rep. R. 415, 416́. 
were proceeded against by information for misconduct. ${ }^{42}$ But there was summary power, and it embraced disobedience to orders, misconduct of officers, and misconduct in the actual view of the court. Except, therefore, for out-of-court contempts by strangers, and possibly by parties, not involving disobedience to process or orders, the summary power of medieval courts was almost modern in scope.

An early example of the summary trial procedure is found in the commitment of an attorney upon interrogation in $1310 ; 43$ and in the middle of the fourteenth century "it was probably common custom to examine an officer charged with malpractice. . . ." 44 This was the practice of examination upon interrogatories which derived from the ecclesiastical courts and prevailed in the King's Council. ${ }^{45}$ It represents a drastic innovation. Gone are the particularized common law pleadings designed to set out the charge precisely, gone the right to trial by jury. Instead the defendant is summoned to answer a complaint by the plaintiff, and, on appearance, to "answer on oath, and sentence by sentence," the bill of the plaintiff. ${ }^{6}$ The justices of both benches were, in the reign of Henry V, assisting in cases pending before the King's Council and thereby becoming familiar with the process of examination. ${ }^{47}$ To this may be added the influence exerted by a long line of statutes, from I 402 onwards, extending the summary trial by examination, among other things, to four specific instances of out-of-court contempts by strangers. ${ }^{8}$

The extension of summary procedure to other out-of-court contempts by strangers may be traced from the summary power over their out-ofcourt disobedience of orders.

At the close of the fourteenth century Chancery was entertaining petitions to punish for contempt not only those who disobeyed, but also those

${ }^{42}$ Fox, op. cit. supra note 32 , at 158.

${ }_{43}$ Ibid., at I59, I6r, I62; Broke v. Taylard, Y.B. 4 Edw. I, 22 Seld. Soc. I94 (I907).

44 Fox, op. cit. supra note 32 , at $73-74$.

45 Ibid., at 70, 73; Maitland, Equity 5 (I929). Note that summary procedure comprises both examination and attachment, which was initially process to secure appearance in court and did not connote trial by examination. Fox, op. cit. supra note 32 , at $56-57$.

${ }^{4}$ Maitland, Equity 5 (I929).

47 Fox, op. cit. supra note 32, at 73; Fox, The Summary Process to Punish Contempt, 25 Law Q. Rev. 354, 356 (Igog).

${ }_{48}^{8}$ Fox, op. cit. supra note 32 , at 77-82. Fox's argument that the explicit statutory authorization in these four instances rules out the existence of a general summary power as to strangers runs afoul of the fact that many statutes dealing with misconduct of officers were only declaratory if by Fox's own testimony disciplinary jurisdiction over court officers was exercised from earliest times. 
who trampled on or were otherwise disrespectful of its orders. ${ }^{49}$ In the middle of the sixteenth century, Chancery began summarily to punish both parties and strangers who resisted the service ${ }^{50}$ or who spoke contemptuously of the court on service of process, ${ }^{5 x}$ i.e., of an order to appear. In this it followed the example of the Star Chamber, which had since I495 exercised jurisdiction over resistance to and slander of the process of other courts. $^{52}$ It is a mistake to impeach the example of the Star Chamber ${ }^{53}$ on the ground of tyrannical excesses at a much later period, for the Star Chamber was a respected and important court as late as the reign of Charles I. ${ }^{54}$ If anything, the instances just recited show that Chancery had anticipated the Star Chamber by punishing disrespect of its orders in the fourteenth century. To be sure, Chapter 39 of the Statute of Westminster II had in 1285 provided for jury trial in cases of resistance to a sheriff in execution of process, ${ }^{55}$ and Fox lists cases subsequent to the statute in which resistance to execution of process, and contemptuous reference thereto-plainly an extension of statutory authority, which was later taken up in the summary procedure-were tried by jury. ${ }^{56} \mathrm{We}$ are not, without more, justified in construing the statute as a limitation upon the summary power over disobedience to orders, of which resistance to process

49 Select Cases in Chancery, ro Seld. Soc. 26,60, 78 (r896).

so Rove v. West, Cary 38, 2 I Eng. Rep. R. 2 I (I558); Dastoines v. Apprice, Cary 92, 21 Eng. Rep. R. 49 (1579). The following cases are found in Monro, Acta Cancellariae (1847): St. Johns College v. Pinder (1557) (examination upon interrogatories), at 334; Inhabitants of Lynde v. Byron (1563), at 345; Clement v. Champion (1564), at 352; Churchhouse v. Sherwyn ( 1566 ), at $36 \mathrm{r}$; Wheteley v. Fenner (1568), at 374; Bowyer v. Samwayes (1572), at 394 ; see ibid., at $4 \mathrm{II}, 4 \mathrm{I} 4,50 \mathrm{I}, 504,542,546,549,57 \mathrm{I}, 65 \mathrm{I}, 753$.

5z Allen v. Martin ( 1600 ), Monro, Acta Cancellariae 753 (1847); cf. Lingen v. Prince (1582), ibid., at $5^{\mathrm{I} 6}$.

52 Fox, op. cit. supra note 32, at Io9; Idele v. Abbotts, I Select Cases in the Star Chamber, I6 Seld. Soc. 50 ( 1902 ). Fox cites the summary punishment of "an attempt to discredit justice and jury" in a murder case during the reign of Philip and Mary. Fox, op. cit. supra note 4r, at 273 ; Fox, op. cit. supra note 32 , at 84 , I16; compare the case of the seizure and detention of the duly elected "bailly" by certain persons displeased with his election "in contempt of your highness and your lawes." I Select Cases in the Star Chamber, I6 Seld. Soc. 230-3I (rgo2).

53 Fox, op. cit. supra note 32, at 88; Frankfurter and Landis, op. cit. supra note 5, at ro45.

${ }^{54}$ See the comment of Judge Frank in NLRB v. Air Associates, Inc., I2I F. (2d) 586, 589 n. 4 (C.C.A. $2 \mathrm{~d}$ x94I), and the authorities there cited; Scofield, Court of Star Chamber 45 (rgoo); Crompton, Star Chamber Cases x (188I); Turner, Star Chamber, Encyc. Brit. $33^{\mathrm{I}}$ (r4th ed. 1936); Palgrave, The Original Authority of the King's Council rog-ro (1834); Carr, Concerning English Administrative Law I26 (I94r).

ss Fox, op. cit. supra note 32 , at $\mathrm{YI}-\mathrm{I2}$.

${ }^{56} \mathrm{Ibid}$., at 229-30. 
was merely a branch..$^{57}$ And a striking departure is found in the dreaded writ of subpoena, first met in $136_{3}$, which cut through the interminable delays that hamstrung common law process, ${ }^{8}$ apparently by means of summary enforcement rather than the recited pecuniary penalty.59 Even if punishment for contempt of judicial orders, tested by the Statute of Westminster II, represented an arrogation of judicial power, it was nevertheless an established practice by the end of the sixteenth century, and had found formal expression in Lord Bacon's Order No. 77 in I6I9. ${ }^{60}$

In short, given the ancient jurisdiction to proceed summarily for disobedience of judicial writs and orders, the extension of the contempt power could and did proceed by easy steps. Fox's sketch of the development in terms of disobedience of mesne process is no less applicable to disobedience of all orders. There was the

Ist step, disobedience to the writ; $2 \mathrm{~d}$, abuse of the process server; $3 \mathrm{~d}$, assaulting him; 4th, abusing the writ; $5^{\text {th }}$, abusing the Court or Judge by whose authority the writ issued; 6th, reducing the abusive words into writing and publishing them; and so the offender arrives at a libel on the Court. The first five steps, ending with abuse of the Judge, were punishable by summary procedure in the Court of Chancery under Lord Bacon's rule, and in the King's Bench after the abolition of the Star Chamber; the sixth, libelling the Court or Judge, was not so dealt with either in the Court of Chancery or at common law, where the contempt was denied, until the eighteenth century. ${ }^{6 x}$

As we have seen, Chancery had reached the fourth step, abuse of the writ, by the end of the fourteenth century when it was entertaining petitions to punish for contempt those who had trampled on its orders. And by the end of the sixteenth century it was summarily punishing those who abused the court during the service of process (fifth stage). From this it was but a step to commitment for any spoken contempt. There is reason to believe that the step had in fact been taken by the time of Lord Bacon's rule. That rule stated: "In case of contempts granted upon force or ill words upon serving of process, or upon words of scandall of the Court, proved

57 Jury trial in cases of resistance to execution of a writ was not a novelty. See the cases decided in 1254 and 1276 , cited in Fox, op. cit. supra note 32, at 226. Perhaps the statute was merely intended to warn the "great men" who alone are mentioned as "resisters" and to embolden the courts to deal with them.

${ }^{88}$ I Holdsworth, op. cirt. supra note 35 , at 485 n. 9; 3 ibid., at 623-27.

s9 Palgrave, op. cit. supra note 54, at I3r; I Spence, Equitable Jurisdiction 369-70 (I846) (authority in the reign of Edw. IV cited); I Campbell, Lives of the Lord Chancellors 259 (5th ed. I868); cf. I Holdsworth, op. cit. supra note 35 , at 406 n. 6 .

60 Sanders, Chan. Ord. IIg (I845).

6: Fox, op. cit. supra note 32 , at I09-10. 
by affidavit, the party is forthwith to stand committed." ${ }^{362}$ Fox suggests that the phrase "words of scandall of the Court" must "be taken to mean only in connexion with the service of process." ${ }^{\prime \prime 3}$ But that situation was plainly covered by the phrase "ill words upon service of process," and Lord Bacon was the last man to add purely tautologous matter.

Parliament itself had set the example as early as $\mathrm{I}_{52}^{29}$, when William Thranwis was committed for a contempt in words against the House. ${ }^{64}$ An unbroken line of summary commitments for "contumelious words against the House," stretching from 1558 to the case of Sir Francis Burdett in I8Io, is recorded in the Journal of Parliament.65 The practice of commitment for out-of-court contempts had found judicial approval in Ferrers' Case in $1543 .{ }^{66}$ These cases, and a commitment for libel of the House by one Hall in 1580 , are cited by Lord Ellenborough for the proposition that the "House were in the habit of committing for contempt." The power was likewise recognized by Chief Justice Holt, ${ }^{68}$ Lord Eldon, ${ }^{69}$ and Lord Erskine, who declared that the "House of Commons . . . . must, like every other tribunal, have the power to protect itself from obstruction and insult. ...." "7o So long continued and familiar a practice necessarily influenced the courts; and Fox is plainly mistaken in suggesting that the courts were reflecting the practice of the House in the later Stuart period, ${ }^{7 x}$ for judicial approval reaches back to 1543 .

Such is the setting against which the development of the power in the law courts is to be viewed. In I6I5, Chief Justice Coke clearly thought he had the power of punishing summarily a person who had treated the proc-

${ }^{62}$ Sanders, Chan. Ord. Irg (1845) (italics added); cf. Lingen v. Prince (1582), reported in Monro, Acta Cancellariae $5 I 6$ ( 1847 ), involving a commitment for contemptuous words spoken against the court, though it does not appear where or in what connection the words were spoken. Compare the commitment of counsel for out-of-court criticism of the Lord Chancellor in Brokas v. Savage ( 1588 ), ibid., at $58 \mathrm{r}$. See the curious Chancery case in 1396 in which John Belgrave was charged with placing in a church, in which an ecclesiastical hearing was to take place, a bill terming the hearing officer an unrighteous judge to the detriment of the execution of the laws. Select Cases in Chancery, ro Seld. Soc. 106 (1896).

${ }_{3}$ Fox, op. cit. supra note 32 , at rog.

${ }_{64}$ Unreported, but cited by Lord Ellenborough in Burdett v. Abbott, I4 East I, 142, 104 Eng. Rep. R. 5or, 555 (K.B. $x 8 \mathrm{Ir}$ ).

65 The cases are listed in ibid., at $23-26$.

${ }^{66}$ Bridgman 625, I24 Eng. Rep. R. 282 (I63I). ${ }^{67}$ Note 64 supra.

${ }^{68}$ Regina v. Paty, 2 Ld. Raym. r105, Ir15, 92 Eng. Rep. R. 232, 238 (K.B. r705).

${ }^{69}$ Burdett v. Abbott, 5 Dow I65, 200, 3 Eng. Rep. R. I289, I30I (H.I. 1817).

${ }^{70} \mathrm{Ibid}$., at 201 and 2302; see the Earl of Shaftesbury's Case, I Mod. I44, I58, 86 Eng. Rep. R. 792, 800 (K.B. I677); Murray's Case, I Wils. (K.B.) 299, 95 Eng. Rep. R. 629 (175I); Brass Crosby's Case, 3 Wils. (K.B.) I88, 95 Eng. Rep. R. 1005 (I77x).

${ }^{7 x}$ Fox, op. cit. supra note $4 \mathrm{I}$, at $275-76$. 
ess of King's Bench with contempt. ${ }^{72}$ An attempt had been made in 1594 in the Queen's Bench to combine the processes of attachment and examination with respect to a contempt by a stranger out of court.73 The order then entered apparently came to naught, but there is evidence of examination upon attachment in I63I. ${ }^{74}$ Fox remarked that there "is no doubt that summary committal for contempts out of court, except in case of libel on the court.... was practiced by the common law courts in the middle of the seventeenth century." "75 To discredit the practice by attributing it to the example of a decadent Star Chamber and an arbitrary Restoration Parliament is to ignore the play of forces emanating from the long-familiar parliamentary practice, the well-settled practice of an honored Star Chamber, and, by I600, the established Chancery practice with respect to slander on the service of process.

The eighteenth century saw the summary power in spate, sweeping on in case after case to encompass contempts by publication. On the King's Bench side were ${ }^{76}$ Rex v. Barber ${ }^{77}$ Rex v. Wilkin, ${ }^{78}$ Rex v. Colbatch, ${ }^{79}$ Rex v. Middleton, ${ }^{80}$ Rex v. Wiatt, ${ }^{81}$ Rex v. Lawley, ${ }^{82}$ Anonymous Case, ${ }^{83} \operatorname{Rex} v$.

$7_{2}$ Bruistone v. Baker, I Rol. 315, 8I Eng. Rep. R. 5II (K.B. I6I5); 3 Holdsworth, op. cit. supra note 35 , at $394 \mathrm{n}$. 2. Fox stated that this case indicated that a practice of examination upon oath had been "established in Coke's time in some cases." Fox, The Summary Process to Punish Contempt, 25 Law Q. Rev. 238, 250 (rgog).

73 Fox, op. cit. supra note 32 , at 86.

74 Ibid., at 87,89 . Plucknett stated that the King's Bench, by the end of the sixteenth century, enjoyed considerable powers of summarily trying the more usual contempts. Plucknett, op. cit. supra note 40 , at $27 x$.

${ }^{75}$ Fox, op. cit. supra note 72, at 366 . Style's Practical Register $\left(\mathrm{r}_{57}\right)$ under "Attachment": "Generally an attachment doth lie for any contempt done against the court."

${ }^{76}$ Some of the cases are listed in Reports of the Select Committee of the House of Commons appointed to consider Sir Francis Burdett's case, at appendix E, 8 How. St. Tr. I4, 49 (I810), and are discussed in Fox, op. cit. supra note 32, at 25, I1 2-14, I6, 28, 30, 35, 107. Compare the comment of Lord Kenyon on a commitment for libel by the House of Lords: "This claim of right to punish ... . for such an offense is not peculiar to the House of Lords; it is frequently exercised by this and other courts of record, and that not merely for contempts committed in the presence of the court." Flower's Case, 8 Term R. 314, 323-24 ( 1799 ).

77 I Stra. 444, 93 Eng. Rep. R. 624 (I721).

${ }^{8}$ Unreported (I722).

79 Unreported (1723).

${ }^{80}$ Fortes. 20x, 92, Eng. Rep. R. 818 (1723).

$8 x 8$ Mod. 233, 88 Eng. Rep. R. 96 ( 1723$)$. Fox wrote: "The reports in the Middleton and Wiatt cases mistakenly read as if the libel were against a Docitor of Divinity, but it is clear that attachment would not have been granted in the case of a libel on a private individual. The libel in fact contained expressions reflecting on the Court, and the case is so indexed in the Table to 8 Modern and in Viner's Abridgement (vol. xv, p. 90, pl. 3)." Fox, op. cit. supra note 32 , at II3.

${ }^{82}$ Unreported (I73I). $\quad{ }^{83} 2$ Barn. (K.B.) 43, 94 Eng. Rep. R. 345 (I73I). 
Carroll, ${ }^{84}$ Rex v. Almon, ${ }^{85}$ and Steare's Case. ${ }^{86}$ On the Chancery side were ${ }^{87}$ Poole v. Sacheverel, ${ }^{88}$ In re Dodd, ${ }^{89}$ Raike's Case, ${ }^{90}$ Roach v. Garvan, ${ }^{97}$ and Cann v. Cann.92 "Standing by themselves," said Fox, these cases "point

${ }^{84}$ I Wils. 75 (I744).

${ }^{85}$ The draft of Chief Justice Wilmot's opinion in Rex v. Almon has been brushed aside as posthumous. Fletcher, J., dissenting in Taafe v. Downs ( $\mathrm{I} \mathrm{r}_{3}$ ), quoted in Fox, op. cit. supra note $4 \mathrm{x}$, at 187 ; Frankfurter and Landis, op. cit. supra note 5 , at I046. The copy of his opinion, published in I802, shows by his endorsement that his brother judges would have agreed in granting the attachment, and more important, it has been explicitly endorsed by the English courts. For citations see Fox, op. cit. supra note 32 , at 30 . Compare the posthumous opinion of Taney, C.J., in Gordon v. United States, II7 U.S. 697 (1864); Frankfurter and Katz, Cases on Federal Jurisdiction $\mathrm{I}_{3}$ (x93 I). It was natural that Chief Justice Wilmot, casting about for precedents in a case involving a libel on King's Bench in $x_{7} 65$, should inquire why the printing of scandalous attacks on a judge should go unpunished when attachments were being granted for abusing the process of the Court. Rex v. Almon, Wilm. 243, 256-57 (K.B. r76s).

For parallel independent reasoning see Commonwealth v. Dandridge, 2 Va. Cas. 408, 420 (1823). To this query Fox replied that obstruction of a process server directly interferes with the course of justice whereas a libel on a court is an indirect contempt. Fox, op. cit. supra note 32 , at 1 ro. But the distinction between spoken contempts on service of process (which alone are involved) and a libel on the court is unreal. For, as was noted in the Dandridge case, op. cit. supra, at 428 , "the process is just as effectual for its end and purpose though spoken of contemptuously, as if received in silence or treated with professed respect." Certainly a slanderous reflection on process can scarcely have a more immediate obstructive effect than a widely published attack on the integrity of the court, particularly when similar cases are pending.

${ }^{86}$ Unreported (x768).

${ }^{87}$ The cases are discussed in Fox, op. cit. supra note 32, at 2I-22, II5, IOI, 102; see Ex parte Jones, 13 Ves. 237, 33 Eng. Rep. R. 283 (I806).

${ }^{88}$ I P. Wms. 675, 24 Eng. Rep. R. 565 (I720).

89 Sanders, Chan. Ord. 538, 542 (r736).

9o Unreported (I740).

${ }^{2} 2$ Atkyns 469, 26 Eng. Rep. R. 683 (1742).

922 Ves. Sr. 520 (1754). The Cann and Pool cases involve publications of matter relating to the case, rather than criticisms of the court. Of the two groups of cases listed above, the Barber, Wilkin, Colbatch, Middleton, Lawley, Anonymous, Dodd, Raike, Almon, and Steare cases involved libels on the court; and Lord Hardwicke by dictum in the Garvan case mentioned "scandalizing the court" as one of the contempt categories. See note 96 infra; Regina v. Skipworth, I2 Cox C.C. 37 r (Q.B. I873); Regina v. Gray, [I900] 2 Q.B. 36 (non-pending case). Rex v. Editor, 44 T.L.R. 30I (K.B. I928); Goodhart, op. cit. supra note I4, at 898-904. The foregoing historical materials plainly disclose that "scandalizing the court" is traceable in a direct and logical line from one of the earliest branches of the contempt power, and that it is an accepted doctrine in England today.

The doctrine found acceptance in this country from the beginning; see Respublica v. Oswald, r Dall. ( $\mathrm{Pa}.)^{*}{ }_{39}$ ( 1788 ), and the concession by the learned Storrs in the Peck impeachment proceedings, note 162 infra. See also State v. Morrill, I6 Ark. 384 (I855); Ex parte Barry, 85 Cal. 603, 25 Pac. 256 (r89o); Cooper v. People ex rel. Wyatt, i3 Colo. 337, 22 Pac. 79० (I889); In re Hayes, 72 Fla. 558, 73 So. 362 (I9I6); In re Fite, II Ga. App. 665, 76 S.E. 397 (IgI2); Ray v. State, 186 Ind. $396, \mathrm{II}_{4}$ N.E. 866 (IgI7); In re Chadwick, Iog Mich. 588, 67 N.W. I07I (I896); State v. Shepherd, I77 Mo. 205, 76 S.W. 79 (I903); Terri- 
to modern innovation rather than to immemorial usage. . . ."93 This is a just refutation of Chief Justice Wilmot's rash claim. But it goes no further. The towering structure of equity itself would fall were its foundation sought in immemorial usage. ${ }^{94}$ And these cases do not stand alone; they are the product of an evolution typical of the common law.95 If the foregoing analysis is valid, the contempt power over publications was established at the adoption of the Constitution. ${ }^{96}$

\section{THE CONSTITUTION AND THE CONTEMPT POWER}

The "sweeping constitutional mandate against any law 'abridging the freedom of speech or of the press" " not alone curtails the summary power of state courts, holds the Bridges case, but, the Supreme Court plainly intimates, it limits the power of federal courts, including the Supreme Court itself. ${ }^{97}$ The majority, consequently, looks to the First Amendment both for light as to the scope of the Fourteenth and as a direct limitation upon the summary power of federal courts. "Congress shall make no law .... abridging the freedom of speech or of the press," declares the First Amendment. On its face this prohibition applies only to laws enacted by Congress. Whatever be the scope of that limitation, how can a restriction aimed squarely at the legislative power be construed as a limitation upon

tory v. Murray, 7 Mont. 25I (I887); In re Moore, 63 N.C. 389 (I869); State v. Hildreth, 82 Vt. $3^{82}, 74$ Atl. 7 I (Igo9); Burdett v. Commonwealth, Io3 Va. 838 , 48 S.E. 878 (Ig04); State v. Frew \& Hart, 24 W.Va. 4I6 (1884); Nelles and King, op. cit. supra note 16, at 537. Mr. Justice Holmes has summed up this learning in the statement that courts which find "that publications impugning their own reasoning or motives will interfere with their administration of the law" may act summarily. Patterson v. Colorado, 205 U.S. 454, 462-63 (Igo7). But cf. Mr. Justice Frankfurter's dissent in Bridges v. California, 3I4 U.S. 252, 287 (rg42); note $3^{6}$ supra.

93 Fox, op. cit. supra note 32 , at III, II2 (italics added).

${ }_{94}$ See note 35 supra.

${ }^{95}$ As in the case of agreements in restraint of trade, the common law has at times "reversed its old doctrine." Pollock, Principles of Contract 39I-92 (Ioth ed. 1936).

${ }_{96}$ The testimony of contemporary writers is found in 5 Viner, Abridgement $442-53$ ( 5 th ed. I792); 3 ibid., at 236-37 (5th ed. I791); 2 Hawkins, Pleas of the Crown c. $22 \$ 3^{6}$ (6th ed. r788), citing Rex v. Barber, I Stra. 444 (K.B. $172 x$ ); 4 Bl. Comm. *282-85; 2 Comyn's Digest 38-42 (2d ed. $x_{785}$ ). Nor must the importance of Bateman v. Conway, I Bro. Parl. Cas. 5 I9 (H.L. I753) be overlooked in appraising the status of strangers. In that case the House of Lords approved the attachment of a stranger for an out-of-court non-publication contempt. For similar cases see Lea's Case, Gouldsb. 33 (K.B. I586); Partridge v. Partridge, Toth. 404I, 2 I Eng. Rep. R. II7 (Ch. I639); Harvey v. Harvey, 2 Cas. in Ch. 82, 22 Eng. Rep. R. 857 (I68I); Butler's Case, 2 Salk. 596, 9I Eng. Rep. R. 504 (K.B. I696); Garibaldo v. Cagnoni, 6 Mod. 9o, 87 Eng. Rep. R. 848 (K.B. x704); Yalden's Case, I P. Wms. 697, 24 Eng. Rep. R. 576 (Ch. x721); Williams v. Iyons, 8 Mod. I89, 88 Eng. Rep. R. I38 (K.B. r723).

97 Bridges v. California, 3 I4 U.S. 252, 260 (I94I). 
a familiar co-existing judicial power?98 The appeal to history by Mr. Justice Black furnishes no adequate answer.

Historically, it is generally agreed that the guarantee of free press was largely designed to bar the Federal Government from licensing or censoring the press. ${ }^{99}$ English licensing had by the lapse of a statute expired in I694, though it maintained itself in the colonies until I 7I9. ${ }^{\text {xoo }}$ Toward the end of the eighteenth century, the dormancy of the licensing power had become identified with a common law right of free press which first found legal formulation at the hands of Blackstone. ${ }^{\text {Ior }}$ The "liberty of the press," said Blackstone, whose influence with the colonists is well-known, "oz "consists in laying no previous restraints upon publications and not in freedom from censure for criminal matter when published." ${ }^{{ }_{103}}$ It seems improbable that the framers of the Amendment intended to soar far beyond common law confines. ${ }^{\text {xo4 }}$ For this we have early judicial testimony, as well as that of the great commentators Story and Kent, and more recently, of Mr. Justice Holmes. ${ }^{105}$ But why, it has been asked, should the colonists have troubled to push through a constitutional amendment "just to settle

$9^{8}$ Compare the parallel provision that "No State shall ... . pass any . . . Law impairing the Obligation of Contracts" which time and again has been held inapplicable to impairment by judicial decision. Tidal Oil Co. v. Flanagan, 263 U.S. 444 (I924), and cases cited therein; Stockholders of the Peoples Banking Co. v. Sterling, 300 U.S. I 75 (r937); Constitutionality of Judicial Decisions in Their Substantive Law Aspect under the Due Process Clause, 28 Col. L. Rev. 619, 627 (I928). "Insofar as the semantics of the eighteenth and early nineteenth centuries are concerned, the word 'Iaws' did not include decisions but was limited to legislative enactments." Teton, The Story of Swift v. Tyson, 35 Ill. L. Rev. 5I9, 537 (I94I), and materials there cited.

992 Story, Commentaries on the Constitution 597-98 (2d ed. 185 I); I Kent, Commentaries 627 (7th ed. $185 \mathrm{r}$ ); Pound, Equitable Relief Against Defamation and Injuries to Personality, 29 Harv. L. Rev. 640, 65r (rgr6); cf. Patterson v. Colorado, 205 U.S. 454 (Ig07) (per Mr. Justice Holmes); Near v. Minnesota, 283 U.S. 697, 7I3 (I93I) (per Mr. Chief Justice Hughes); see page $6 \mathrm{r} 8$ infra.

${ }^{{ }^{100}} 2$ Story, op. cit. supra note 99, at 599; Vance, Freedom of Speech and of the Press, 2 Minn. L. Rev. 239, 247 (I9I8).

zox Pound, op. cit. supra note 99, at 650; Corwin, Freedom of Speech and Press under the First Amendment: A Résumé, 3० Yale L. J. 48, 49 (1920).

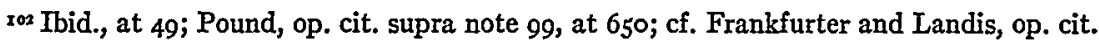
supra note 5 , at $1046 \mathrm{n}$. I 28 .

${ }^{{ }^{0}{ }_{3}} 4$ Bl. Comm. * ${ }^{15}$ I.

ros Corwin, op. cit. supra note ror, at 49; Pound, op. cit. supra note 99, at 65I. All "that the earlier sages of the Revolution had in view," according to Kent, was to erect "barriers against any previous restraints upon publication." I Kent, Commentaries 627 (7th ed. I85I); see Robertson v. Baldwin, 165 U.S. 2x5, 28I (r897).

zos Respublica v. Oswald, I Dall. (Pa.) ${ }^{*}{ }_{3}{ }_{9}$ ( 1788 ); note 99 supra. For a qualification by Mr. Justice Holmes, see note $17 \mathrm{r}$ infra. 
an issue that had been dead for decades?"'ro6 The answer is best given in the words of St. George Tucker, a native annotator of Blackstone, who gave the common law a "strangely republican twist." lapse of licensing which established the freedom of the press in England, Tucker wrote:

But although this negative establishment may satisfy the subjects of England, the people of America have not thought proper to suffer the freedom of speech, and of the press to rest upon such an uncertain foundation, as the will and pleasure of the government. Accordingly .... the first congress .... proposed an amendment .... "that congress shall make no law abridging the freedom of speech, or of the press." "'08

This was likewise the explanation offered by Story. ${ }^{\text {rog }}$ And, it is submitted, this is all that Madison meant when he declared that "the freedom of the press and rights of conscience, those choicest privileges of the people, are unguarded in the British Constitution." "rro

Admittedly, the Blackstonian interpretation was from early times criticized on the ground that subsequent punishment under repressive laws might as effectively stifle harmless publication as previous restraints. In the words of Madison: "It would seem a mockery to say that no laws should be passed preventing publications from being made, but that laws might be passed for punishing them in case they should be made." ${ }^{\prime 1 x}$ This feeling found powerful expression in the English movement led by Fox and Erskine to reform repressive libel laws, culminating in Fox's Libel Act of $x 792 .^{\mathrm{xz}}$ But it is of great significance that these leaders, though indubitably familiar with the summary power over contemptuous publications, should have ignored the "threat" to free speech inherent in the power and confined themselves exclusively to reforming libel trials by jury.

${ }^{106}$ Chafee, Freedom of Speech in War Time, 32 Harv. L. Rev. 932, 945 (rgIg).

${ }^{207}$ Hamilton and Adair, The Power to Govern 20r-2 (r937). Tucker was professor of law at William and Mary, and a judge of the General Court of Virginia. It is at least singular that so "republican" a glossator, one thoroughly alive to the difference between English and American limitations on free press, should have been completely oblivious of the "menace" to free press implicit in Blackstone's sweeping formulation of the summary power over publications.

${ }^{208}$ I Bl. Comm. pt. 2, app. at $x_{3}$ (Tucker ed. $x 803$ ).

${ }^{\text {rog }} 2$ Story, op. cit. supra note 99, at 399.

Iro $x$ Annals Cong. 434 ( 1789 ), quoted in Bridges v. California, 3 r $_{4}$ U.S. 252, 264 (I94r).

sxx 6 Writings of James Madison 386 (Hunt ed. rgo6) (italics added). These remarks, parenthetically, occur in the same discussion of free speech from which Mr. Justice Black culled the quotation that the "common law cannot be admitted as the universal expositor of American terms. ...." Bridges v. California, 3I4 U.S. 252, 265 n. Io (I94I); see Near v. Minnesota, ${ }_{28}$ U.S. 697, 7I4-I5 (I93I). As Chafee puts it: "A death penalty for writing about socialism would be as effective suppression as a censorship." Chafee, op. cit. supra note ro6, at 940.

ra Chafee, op. cit. supra note ro6, at 939, 945. 
Lord Erskine, in fact, later approved the contempt power over publications. ${ }^{\times 3}$ Chief Justice Hughes summarized the matter in Near v. Minnesota, a decision that went far to extend protection to the press:

But it is recognized that punishment for the abuse of the liberty accorded to the press is essential to the protection of the public, and that the common law rules that subject the libeler to responsibility for the public offense, as well as for the private injury, are not abolished by the protection extended in our constitutions.... The law of criminal libel rests upon that secure foundation. There is also the conceded authority of courts to punish for contempt when publications directly tend to prevent the proper discharge of judicial functions. ${ }^{174}$

The general statements by Madison, cited by the majority, to the effect that "the state of the press . . . under the common law, cannot . . . .

${ }_{113}$ Burdett v. Abbott, 5 Dow 165, 200, 3 Eng. Rep. R. I289, I302 (H.L. I8I7). See also his statement in the text at note 70 supra. A word against the temptation to equate contemptuous publications with seditious libels. According to Stephen, the eighteenth century defined seditious libel as "written censure upon public men for their conduct as such, or upon the laws, or upon the institutions of the country." 2 Stephen, The History of the Criminal Law of England 348 ( $188_{3}$ ). This language, to be sure, is broad enough to include publications which "scandalize" the courts. But Blackstone does not make the identification. Instead, he treats them in separate categories, explaining that libels, "especially of a magistrate," may lead to breach of the peace by inciting "to revenge, and perhaps to bloodshed." $4 \mathrm{Bl}$. Comm. *I5O. Punishment for contemptuous publications, on the other hand, proceeds from the need for law enforcement, since "laws, without a competent authority to secure their administration from disobedience and contempt, would be vain and nugatory." Ibid., at *282. And summary punishment of contemptuous publications has a line of descent quite distinct from that of the crime of libel. Page 606 supra. Moreover, despite the frequent trials for seditious libel, the leading contempt cases do not cite them as analogies, nor do the leading seditious libel cases invoke the contempt cases.

Indeed, Erskine, who had been preeminent for the defense in the leading seditious libel cases, plainly excepted contempts from the broad protection of free press. Thus, in the argument on behalf of Thomas Paine, he said that if one "calumniates living magistrates . . . . he is then a criminal upon every principle of rational policy, as well as upon the immemorial precedents of English justice. ... ." Paine's Case, 22 How. St. Tr. 358, 4I5 (K.B. I 792); ibid., at 424. Again, referring to the need to preserve the "impartial administration of justice," Erskine said that the "circulation of any paper" that tends to prejudice a "British tribunal" is "highly criminal," a quite inclusive formula guarding "freedom of trial." Ibid., at 4I7. Finally, emphasis upon incitement to disaffection, to violent alteration of established institutions, runs through the libel cases; see Dean of St. Asaph's Case, 2 I How. St. Tr. 847, 898, 906, rorr (K.B. 1784). It is therefore understandable that, as fear of revolution diminished, English prosecutions for seditious libel practically ceased, 2 Stephen, op. cit. supra, at 373, whereas English courts continue to punish contemptuous publications because they obstruct the administration of justice. See note 92 supra.

${ }^{114}$ Near v. Minnesota, 283 U.S. 697, 715 (I93I). Cf. Frohwerk v. United States, 249 U.S. 204 (IgIg); Schenck v. United States, 249 U.S. 47 (I9I9); Gitlow v. New York, 268 U.S. 652 (1925). Compare the many early constitutional provisions proclaiming the responsibility of those who enjoyed a free press for its "abuse." Cf. the Pennsylvania Constitution of 1790,2 Poore, Constitutions and Charters 1554 (2d ed. I878). 
be the standard of its freedom in the United States,"Irs do not impair the position that the contempt power was untouched by the guarantee of free press. As their immediate context shows, these statements were merely intended to emphasize, in the course of the controversy that raged about the Alien and Sedition Laws, that Americans, in contrast to the English, were protected against subsequent punishment under laws as well as prior executive licensing. Madison's statement immediately preceding the last quotation makes this emphatically clear: "In the United States the great and essential rights of the people are secured against legislative as well as against executive ambition. ... . This security of freedom of the press requires that it should be exempt not only from previous restraints by the Executive, as in Great Britain, but from legislative restraint also; and this exemption, to be effectual, must be an exemption not only from the previous inspection of licensors, but from the subsequent penalty of laws." ${ }_{\text {Ir6 }}$

We turn to contemporary constructions that are more directly in point. It will be recalled that there was an established summary power over contemptuous publications at the adoption of the Constitution. In I $_{79} 8 \mathrm{Con}$ gress conferred upon the federal courts the power to punish for contempts, ${ }^{\mathrm{Ix}} \mathrm{a}$ a grant which the Supreme Court before long held was merely declaratory of the inherent judicial power. ${ }^{118}$ Acting under a Constitution that set up courts of "law and equity" after the English pattern, and prompted by the statutory technical term, contempts, the courts properly turned to the common law for light as to the scope of their powers. ${ }^{\mathrm{Ix}}$ That the courts would in consequence emerge with summary punishment for contemptuous publications could not have been unforeseen by Congress. Just one year before the Act of $x 789$, Respublica v. Oswald ${ }^{x 20}$ - a case that

Ixs Bridges v. California, $3_{4}^{14}$ U.S. 252, 264 (I94I); 6 Madison, op. cit. supra note IIr, at 387.

${ }^{216} 6$ Madison, op. cit. supra note III, at 387 . Mr. Justice Black quotes Schofield's statement that "one of the objects of the Revolution was to get rid of the English common law on liberty of speech and of the press." Freedom of the Press in the United States, 9 Pub. Am. Sociol. Soc. 67, 76 (rgr 4 ); Bridges v. California, 344 U.S. 252, 264 (r94r). But Schofield cites no authority for the proposition that the contempt power was curbed.

- II7 Judiciary Act of $1789, \S$ I7, x Stat. 83 (I789).

${ }_{118}$ United States v. Hudson \& Goodwin, 7 Cranch (U.S.) *32, *34 (18I2); Anderson v.

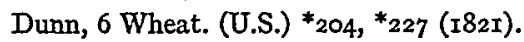

II Cf. the statement of Harlan, J., in Savin, Petitioner: "The act of $I 789$ did not define what were contempts. .... Under that statute the question whether particular acts constitute a contempt .... was left to be determined according to such established rules and principles of the common law as were applicable to our situation." Savin, Petitioner, I3I U.S. $267,275-76$ ( 1889$)$.

${ }^{220}$ I Dall. (Pa.) * 3 I9 (I788), discussed in Nelles and King, op. cit. supra note I6, at 4IO, 4r2. Echoes of the case even reached Jefferson in Paris. He then wrote the details of the case 
excited widespread public interest-was tried in Philadelphia under the very nose of Congress. Oswald, arrested for publishing a libel upon one Browne, published an article stating that he could not expect a fair trial because of the prejudice of the bench, and because Browne was merely a tool of Dr. Rush, a brother of a member of the Pennsylvania court. This was plainly an attempt to "create a public sentiment which would deter a jury from a just finding of his guilt in the libel case. . . . ." ${ }^{x_{22}}$ and Oswald was attached for contempt. The case is especially significant because the protection of the state free press clause was expressly invoked ${ }^{122}$ and unequivocally denied - some three years before the adoption of the federal Bill of Rights. Chief Justice McKean of the Supreme Court of Pennsylvania, a signer of the Declaration of Independence ${ }^{\mathrm{x} 3}$ and an "ardent advocate of the Constitution,"

What then is the meaning of the bill of rights, and constitution of Pennsylvania, when they declare, "That the freedom of the press shall not be restrained," and "that the printing presses shall be free to every person who undertakes to examine the proceedings of the legislature, or any part of the government?" .... Will it be said, that the constitutional right to examine the proceedings of government, extends to warrant an anticipation of .... the judgments of the court? .... The futility of any attempt to establish a construction of this sort, must be obvious to every intelligent mind. ${ }^{x 2 s}$

to Shippen, saying that it was "likely to make a noise." 7 Writings of Thomas Jefferson 152 (mem. ed. Ig03). If to this the acceptance of the power by such contemporary writers as Blackstone, Hawkins, Comyn, and Viner, note 96 supra, and the contemporaneous use of the power by Congress in 1795 and 1800 is added, the fact that the framers could not have heard of Rex v. Almon prior to its publication in 1802 becomes irrelevant; cf. Radin, op. cit. supra note 5 , at $6 \mathrm{r}_{4}$. A hasty search of colonial materials suggests that the power was not a nineteenth century exotic; it was employed in Massachusetts in I72I, I Parrington, Main Currents in American Thought I28 (1927), and in Delaware, between I678 and I68I. Records of the Court of Newcastle in Delaware 496-97, 514-18 (rgo4). The Records report another case wherein the sheriff "indytes" a man and his wife for slandering the court. Ibid., at 226. Since no mention is made of jury trial, a strange omission in the light of the almost invariable emphasis upon jury participation where a jury was employed, ibid., at $307,358,410,436,443,45^{8}$, 469 , the case seems to represent summary procedure. Compare the binding over of one Henry Salter to answer for his slander of the court before the Governor of New York. Ibid., at 287.

sax Nelles and King, op. cit. supra note $\mathrm{r} 6$, at $4 \mathrm{rr}$.

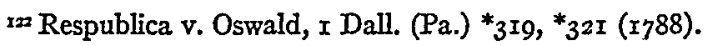

${ }^{123}$ Nelles and King, op. cit. supra note 16 , at 409 n. 45 . Lord Mansfield wrote McKean that the Pennsylvania reports, sent to him by McKean, "do credit to the court .... they show readiness in practice, liberality in principle, strong reason and legal learning." I Dall. (Pa.) *viii ( $\mathrm{r} 788)$.

${ }^{124}$ I Beveridge, Life of John Marshall 332 (Igr6).

${ }^{225}$ I Dall. (Pa.) *3I9, *325 (I788); see Commonwealth v. Brown (I789), decided by the same court. The case is not officially reported but is set out in full in Hamilton, Trial of Justice Shippen 365,425 (1805). 
In I8or the doctrine of the Oswald case received the approval of the Pennsylvania federal circuit court in United States v. Duane, ${ }^{\mathrm{r26}}$ and it was reaffirmed by the Pennsylvania Supreme Court in Respublica v. Passmore. ${ }^{\text {I27 }}$ Shortly thereafter Kent employed the summary power in still another publication case, People v. Freer. ${ }^{\mathrm{x} 28}$ State and federal courts have ever since uniformly declared that the contempt power falls without the ambit of the free speech and press clauses of state constitutions. ${ }^{\text {129 }}$

Congress had in fact set a precedent for the early federal cases. In I800, the Senate, following the English practice earlier noted, attached Duane, the same editor that was subsequently the subject of the contempt proceeding in United States v. Duane, ${ }^{\mathrm{I} 30}$ for a libel on the Senate. The freedom of the press was urged, ${ }^{x^{3}}$ but the Senate voted for Duane's attachment, following the view of Senator Tracy who declared that the contempt power of the Senate was no less requisite than freedom of the press. ${ }^{132}$ Previously the House, in ${ }^{1795}$, had attached Randall for contempt on two charges - bribery of its members, and a slander on the House in that Randall had alleged that some thirty or forty members were already parties to the bribery scheme. ${ }^{\mathrm{3} 3}$ It is highly significant that Madi-

${ }^{126}$ Fed. Cas. No. ${ }^{4}, 997$ (C.C. Pa. $x 801$ ), at 922 . Referring to Oswald's case, the court said: "The present governor of Pennsylvania was then chief justice. He is well versed in the general principles of the law as well as the usages and customs of the United States, and cannot be supposed to have favored constructions unfriendly to true liberty, or unwarranted by the genuine sense of the constitution." See the elaborate examination of the Oswald case by counsel in Hollingsworth v. Duane, Fed. Cas. No. 6,616, at 362 (C.C. Pa. I80x); Fry's Case, cited by counsel in the Peck case; Stansbury, Trial of James H. Peck 352 (1833); Nelles and King, op. cit. supra note 16 , at $428 \mathrm{n}$. I42, $422 \mathrm{n}$. II6.

${ }_{227} 3$ Yeates (Pa.) 438, 44I, 442 ( $\mathrm{x} 802$ ).

${ }^{128}$ x Caines (N.Y.) ${ }_{5} \mathrm{I} 8$ (I804); cf. Yates v. Lansing, 9 Johns. (N.Y.) $396,4 \mathrm{I} 7$ (I8II): "This power extends .... to consequential, indirect and constructive contempts, which obstruct the process, degrade the authority, or contaminate the purity of the court."

I29 State v. Morrill, I6 Ark. 384, 402, 404 (r855); In re Cheeseman, 49 N.J.L. II5, I4I, 6 Atl. 5x3, 516 ( 1886 ); Cooper v. People ex rel. Wyatt, $x_{3}$ Colo. 373, 376 (r889); State ex rel. Haskell v. Faulds, I7 Mont. I40, I45, 42 Pac. 285, 286 (I895); State v. Tugwell \& Baker, I9 Wash. 238, 253, 52 Pac. I056, I06I (1898); State v. Shepherd, I77 Mo., 205, 244, 76 S.W. 79 (I903); Burdett v. Commonwealth, I03 Va. $838,847,48$ S.E. 878 (I904); McDougall v. Sheri-

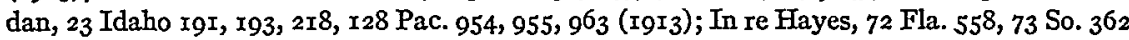
(1916); Dale v. State, $x 98$ Ind. I 10, x24, ז50 N.E. 78x, 786 (I926); In re Stolen, I93 Wis. 602, 216 N.W. I27 (I927); State v. Lovell, II 7 Neb. 710,718 , 222 N.W. 625, 628 (I929); In re Shuler, 210 Cal. 377, 404, 292 Pac. 48I, 493 (I930); cf. Tenney's case, 23 N.H. I62 (I85x); see Watson v. Williams, 36 Miss. 33 I (I858). Contra: Ex parte Hickey, I2 Miss. 75I, 782 (1844).

${ }^{130}$ See note 126 supra.

${ }^{13 x}$ Io Annals Cong. 75,85 (r800).

${ }^{32}$ Ibid., at 87, III, II3.

${ }^{{ }^{333} 5}$ Annals Cong. 168 (I795). The references to the slander charge are in ibid., at 175, I77, 2I4, 2I5. Counsel for Randall asked: "Are the House to lock up the mouths of the people?", Ibid., at 215 . 
son, the advocate of protection for the press against subsequent punishment under laws, should have participated actively in these proceedings without protesting against the exercise by the House of the summary power to curb free speech. ${ }^{\mathrm{I} 34}$ The vote of 78 to $\mathrm{I} 7$ for attachment ${ }^{\mathrm{x} 35}$ in a period of "party dissention and political animosity" ${ }^{36}$ is assuredly the most eloquent testimony of contemporaries, many of whom had joined in submitting the Bill of Rights, that the guarantees of free press were not intended to deprive federal tribunals of the power to repel "disrespect and insult." ${ }_{37}$

The early cases are dismissed without mention by Mr. Justice Black as "attempts to expand" the contempt power which "evoked popular reactions that bespeak a feeling of jealous solicitude for freedom of the press." ${ }_{\mathrm{I}_{3} 8}$ These reactions were episodes in the turbulent struggle for political supremacy between the Federalists and Republicans. Thus Oswald was the editor of a newspaper given to intemperate anti-Federalist abuse, and it is possible to regard his attachment for what was a flagrant and apparently un-political contempt as a covert Federalist gag. ${ }^{39}$ After sentence, Oswald's cause was adopted by members of the Pennsylvania legislature, but a resolution to label the attachment an unconstitutional exercise of judicial power was defeated by a considerable majority, ${ }^{\text {140 }}$ which one again can attempt to explain in terms of Federalist bias..$^{{ }^{x} x}$ What are we to think, however, of the abandonment by Albert Gallatin, a leading Republican, of an attempt to modify the contempt power in the state constitutional convention of I790 on the ground that it was "involved in difficulties" and it was "most prudent to leave the matter'where it stood?" ${ }^{42}$ It is the impeachment proceedings against the members of

${ }^{134}$ At one point Madison expressed himself in "favor of allowing counsel" to defendant. Ibid., at I8r. At another, he pointed out that the elaborate argument was premature since Randall might "save all this trouble" by confessing his guilt. Ibid., at 187 .

${ }^{{ }^{3} 5} 5$ Annals Cong. 220 (I795).

${ }^{136}$ This point was made in the subsequent attachment proceeding of Anderson. 3r Annals Cong. 642 (18r8).

${ }^{137} 5$ Annals Cong. 189 , 193 (1795).

${ }^{238}$ Bridges v. California, 3I4 U.S. 252, 266 (I94I).

${ }^{139}$ Nelles and King, op. cit. supra note 16 , at 4 ro.

${ }^{140}$ Respublica v. Oswald, I Dall. (Pa.) *319, ${ }^{*} 329^{-29 g}$ (r788).

${ }^{{ }^{4} \times}$ The adoption of the Constitution during this very period is susceptible of an explanation in similar terms. And it is worth noting that Oswald "kept up the bombardment of the Constitution and its advocates" after ratification took place in Pennsylvania; cf. I Beveridge, Life of John Marshall 334-38 (IgI6). Madison commented that the "minority . . . o of Pennsylvania has been extremely intemperate. ...." Ibid., at 338 .

${ }^{142}$ Hamilton recites the conversation of Jared Ingersoll, counsel for the justices, a former attorney general of Pennsylvania and a member of the Federal Constitutional Convention, 
the Pennsylvania Supreme Court in 1805 , arising out of the Passmore case, and the attempted impeachment of Federal Judge Peck in I83I, that are chiefly relied on to demonstrate the early belief that summary proceedings were incompatible with the guarantee of free press. ${ }^{{ }^{4} 3}$ Of these in turn.

Passmore sued Bayard and Petit on a policy of insurance and secured a favorable referee's report. The defendants then filed exceptions, whereupon Passmore published a charge that they were "basely" keeping him from his money. He was attached by the Supreme Court of Pennsylvania, where a hearing on the exceptions was pending, and was held in contempt. ${ }^{x 4}$ By this time, be it recalled, contemptuous publications had been punished by the Pennsylvania state and federal courts, and by the Senate and House in the Duane and Randall cases. Consequently there were American as well as common law precedents. Nevertheless the Passmore case was now taken up with a great fanfare in the legislature. Although Hugh H. Breckinridge, the sole Republican member of the Pennsylvania Supreme Court, had not participated in the Passmore proceedings, he endorsed the action of his associates and begged to be impeached with them. ${ }^{\text {.45 }}$ The "fustian character of the whole proceeding" receives its due from Nelles, an unrelenting critic of the contempt power:

A majority of the Republican majority, both in Pennsylvania and in Congress, were, however, at this period bloodthirsty for Federalist judicial scalps. . ... Until I805, when the impeachment of Justice Chase of the Supreme Court failed by two votes, Federalist judicial tenure was precarious. It was touch and go whether impeachment would not become an established procedure for taking the judges of a defeated party out of politics. ${ }^{\mathrm{x}}{ }^{6}$

Touch and go it assuredly was in the Passmore proceedings, for the State Senate voted I3 to II for impeachment, ${ }^{x 47}$ failing by just two votes to attain the majority of two-thirds necessary for impeachment. Even in this jaundiced proceeding, the eminent advocate for the legislature, Caesar

with Peter Duponceau, a noted Pennsylvania lawyer who "never evinced any interest in politics," and a letter from Duponceau to Ingersoll, which sets out the Gallatin incident. Hamilton, op. cit. supra note I25, at 454, 467. Dictionary Am. Biography (r935).

${ }^{243}$ Nelles and King, op. cit. supra note I6, at 4I4, 553; Bridges v. California, 3 I4 U.S. 252 , 264-66 (I94I).

${ }^{I_{44}}$ Bayard and Petit v. Passmore, 3 Yeates (Pa.) ${ }^{*} 48$ et seq., ${ }^{*} 442$ et seq. (r8o2); Nelles and King, op. cit. supra note 16 , at 413 .

${ }^{{ }_{45}} 3$ McMaster, History of the People of the United States ${ }_{559}$ (1892).

${ }^{346}$ Nelles and King, op. cit. supra note 16 , at $4 \mathrm{r} 4$.

${ } 47$ Hamilton, op. cit. supra note 125 , at 49 r. 
Rodney, ${ }^{148}$ conceded that the guarantee of free press did not limit summary punishment of a publication in a pending case, ${ }^{\mathrm{x} 49}$ and indeed the proceeding turned on the specious argument that the case was no longer pending. ${ }^{150}$ The "maddened Republicans" stormed the polls to secure a convention for the purpose of amending the Constitution, but lost. ${ }^{\text {Isx }}$ When they came to power some years later, they limited the contempt power by statute. $^{\text {.52 }}$

We come now to the case most frequently cited for the "abuse" of the contempt power, the "flagrant case of Judge Peck." I53 It is one of the ironies of history that Judge Peck should be singled out as a horrible example, and that he should have waited one hundred years for vindication at the hands of one who strenuously opposed the summary power. The vindication of Judge Peck is a monument to the lofty scholarship of the late Professor Nelles, who alone summoned the patience to disentangle the facts from the morass of Spanish land grant law and Missouri politics out of which the case arose. ${ }^{154}$ Luke Lawless, a crony of Senator Benton of Missouri, and his successor as legal representative of many speculative land claimants, lost a case involving one such claim before Judge Peck, and thereupon published a criticism, artfully temperate in tone, yet as "unfair as can be imagined," ${ }^{\prime 55}$ of Judge Peck's opinion. The case was on appeal at the time of the publication, and it raised the identical issues of numerous cases then pending before Judge Peck. To quote Nelles, "it could have no end except to subject the court to contumely and promote sympathy with the land claimants, making fair juries unobtainable in their cases. ...." ${ }^{156}$ This was obstructing the fair course of justice with a vengeance. Assuming a recognized contempt power, Judge Peck, "exasperated by propaganda in aid of fraud," ${ }^{157}$ had rich justification for its exercise. The

${ }_{x_{4}}^{8}$ Rodney had been one of the Managers for the House of Representatives in the impeachment proceedings of both Federal Judge Pickering and Supreme Court Justice Chase in I804, and became Jefferson's Attorney General in I807. Dictionary Am. Biography (I934).

349 Hamilton, op. cit. supra note I25, at 357 .

${ }^{150}$ This argument was specious because Passmore's own former counsel had advised Passmore that the case was pending and had subsequently declined to represent him in the proceedings. Ibid., at $1_{4} 6, \mathrm{r}_{50}, \mathrm{r}_{52-53}$; cf. ibid., at 8, 20, 49 .

${ }^{\text {IsI }} 3$ McMaster, op. cit. supra note 145 , at 160 ; Nelles and King, op. cit. supra note 16 , at $4 \mathrm{I} 4$.

152 The statute is quoted in Bridges v. California, 314 U.S. 252, $266 \mathrm{n}$. II (I94I).

s53 Ibid., at 287; Thomas, Problems of Contempt of Court 25-27 (i934); Boyd v. Glucklich, II6 Fed. I29, I36 (C.C.A. 8th I902).

Is4 Nelles and King, op. cit. supra note 16 , at 423-30.

rss Ibid., at $428 . \quad \quad{ }^{56}$ Ibid. $\quad$ I57 Ibid., at 525 . 
Congress to which Lawless turned for aid had not been untouched by the "Spanish" land squabbles, and it numbered few more potent statesmen than Senator Benton, himself an advocate of the speculative interests. ${ }^{358}$ Judge Peck narrowly escaped impeachment. We may give thanks that he did, for his impeachment would have been a lasting reproach to American justice. The precedents, and certainly the dicta, ${ }^{x 59}$ might well have led a sound lawyer to believe that the summary power extended to non-pending cases. If he erred, to borrow his own words, Peck erred "in company with judicial characters with whom any judge might be proud to associate."'r6o This argument was emphasized throughout by his great counsel, William Wirt, ${ }^{16 x}$ and a study of the proceedings convinces one that it is unanswerable. Men are not put away for what is at worst a mistake of judgment.

But even the heat of advocacy did not lead the Managers for the House into sweeping denial of the existence of summary power over all contemptuous publications. On the contrary, the Managers, with the exception of Buchanan, repeatedly recognized the common law power over publications in pending cases. Their criticism was reserved for Peck's use of the power in a non-pending case, ${ }^{762}$ and their generalizations about free press are to be viewed in this frame. Nor did these strictures purport to explain how the free press guarantee had limited the contempt power. To be sure, popular repudiation of the Alien and Sedition Laws was used to point

${ }^{2} 8$ Ibid., at $425,426,429$.

159 Rex v. Barber, I Stra. 444 (K.B. I72I), and Rex v. Lawley (I73I) (unreported), were instances of libels on the court in non-pending cases. The dicta of Lord Hardwicke in Roach v. Garvan, 2 Atkyns 469 (Ch. r742), and of Wilmot, J., in Rex v. Almon, Wilm. 243 (K.B. I765), page 6I3 supra, pointed the same way. By this time, it may be added, Rex v. Almon had been expressly approved in Rex v. Clement, 4 B. \& Ald. 2I8, 233 (K.B. I82I), and Rex v. Davison, 4 B. \& Ald. 329, 337 (K.B. I82I).

${ }^{160}$ Stansbury, op. cit. supra note $\mathrm{I}_{26}$, at 45 .

${ }^{16 x}$ Ibid., at $486-97$.

${ }^{162} \mathrm{Ibid}$., at 88, 298, 299, 312, 3I 4 , 3I5, 372, 376, 380, 38I, 382, 395, 400. Early in the argument McDuffie tacitly, ibid., at 88 , and Spencer, ibid., at 298, and Wisclliffe explicitly, ibid., at $3 \mathrm{I} 4,315$, recognized the summary power over publications in pending cases. Meredith, opening for Peck, sought to narrow the issue by stating this concession, but Buchanan rejected the proposition and insisted that there was no power in pending cases as well. Ibid., at 385 . Associate counsel, heeding the dictates of courtesy, of course could not flatly repudiate Buchanan. But Storrs, who followed Meredith, stated the issue in terms of a "libel on the court, not relating to any cause or matter pending. ..." Ibid., at 372 . He repeatedly indicated his acceptance of prevailing case law with respect to pending cases, ibid., at 376, 380, 38r, 382, 395, 400 , saying for example, "We do not deny here that one class of contempt is scandalizing the court. But we say that these scandals must relate to matters pending in judicature before the judges." Tbid., at 382 . These expressions have been explained away as illustrative of the advocates' skill. Nelles and King, op. cit. supra note 16 , at 526 . If we are merely dealing with an exhibition of advocacy, the proceedings have no place as legislative history. 
the moral - that Judge Peck sought to exercise by implication a power denied to Congress. ${ }^{1{ }^{6} 3}$ But the First Amendment expressly denies the power to Congress, not to the courts. Assuming that the Peck proceedings have a wider significance than is here indicated, can an advocate's interpretation, forty years after the adoption of the amendment, be dignified as a contemporary construction? Surely the contemporary judicial and congressional interpretations of the First Amendment earlier noted more accurately reflect the intention of the framers than do the views of the zealous prosecutors in the Peck case forty years after the event. ${ }^{164}$

If the summary power was not limited by the First Amendment, it was not limited by the Fourteenth. Mr. Justice Black recognizes that the Court, under the Fourteenth Amendment, has applied to the states "the same standards of freedom of expression as, under the First Amendment, are applicable to the federal government."'65 Finally, the issue whether the guarantee of free press curtails the summary power was submitted to the Supreme Court in Patterson v. Colorado ${ }^{\mathrm{I} 66}$ and was there decided in the negative in an opinion by Mr. Justice Holmes. The statement by $\mathrm{Mr}$. Justice Black that the Patterson case "cannot be taken as a decision squarely in point" relies on Mr. Justice Holmes' remark that: "We leave

${ }^{163}$ Stansbury, op. cit. supra note 126 , at 90,447 .

${ }^{164}$ Apart from the cases, it is significant that the brilliant Edward Livingston, who leveled a penetrating attack against the contempt power early in the nineteenth century, a criticism that was of great influence, and was in fact argued to the Senate in the Peck case, should have completely ignored the free speech clauses in considering the problem. Stansbury, op. citsupra note I26, at 44I-44, 474; Nelles and King, op. cit. supra note 16 , at 4I8-21, 527 ; I Livingston, Works on Criminal Jurisprudence 258 et seq. (I873). Mr. Justice Curtis, a former member of the Supreme Court, after quoting the Act of $183 \mathrm{I}$, note 178 infra, which was enacted after the Peck proceedings, stated that "the common-law authority of the courts, as it has been exercised in England and in this country, and as it was exercised by Judge Peck . . . extended much wider than this." Curtis, Jurisdiction of the United States Courts I8I-82 (I880).

${ }^{165}$ Bridges v. California, 314 U.S. 252, 268 (I94I). Compare the statement in Mobile \& Ohio R. Co. v. Tennessee, I53 U.S. 486, 506 (1894): "[The Fourteenth Amendment] conferred no new and additional rights, but only extended the protection of the Federal Constitution over rights of life, liberty, and property that previously existed under all state constitutions." Compare the state cases cited in note 129 supra. The expansion of due process to embrace freedom of speech and press dates back only to Gitlow v. New York, 268 U.S. 652 (Ig25). In I922 the Court had stated that "neither the Fourteenth Amendment nor any other provision of the Constitution of the United States imposes upon the States any restrictions about 'freedom of speech.' ..." Prudential Ins. Co. v. Cheek, 259 U.S. 530, 543 (I922). Freedom of speech was traditionally not comprehended by the term "liberty." Warren, The New "Liberty" under the Fourteenth Amendment, 39 Harv. L. Rev. 43I (xg26); Shattuck, The True Meaning of the Term "Liberty" in those Clauses in the Federal and State Constitutions which Protect "Life, Liberty, and Property," 4 Harv. L. Rev. 365 (I8gr).

${ }^{166} 205$ U.S. 454 (I907). 
undecided the question whether there is to be found in the Fourteenth Amendment a prohibition similar to that in the First." ${ }^{67}$ But Mr. Justice Holmes found it unnecessary to decide that question because, assuming that the prohibition was found in the Fourteenth Amendment, he held that it did not limit the contempt power.

The Patterson case grew out of a publication reflecting on the Supreme Court of Colorado, for which the publisher was summarily held in contempt. A motion to quash, based upon the Fourteenth Amendment, was overruled below; Colorado urged in the United States Supreme Court that there was no jurisdiction to review, in the absence of a federal question, since the guarantee of free press did not extend to a publication that obstructed the administration of justice. ${ }^{168}$ On the issue thus presented, Mr. Justice Holmes declared:

We leave undecided the question whether there is to be found in the Fourteenth Amendment a prohibition similar to that in the First. But even if we were to assume that freedom of speech and freedom of the press were protected from abridgment on the part not only of the United States but also of the States, still we should be far from the conclusion that the plaintiff in error would have us reach. In the first place, the main purpose of such constitutional provisions is "to prevent all such previous resiraints upon publications as had been practiced by other governments," and they do not prevent the subsequent punishment of such as may be deemed contrary to the public welfare .... Respublica v. Oswald. ... . In the next place, the rule applied to criminal libels applies yet more clearly to contempts. A publication likely to reach the eyes of a jury, declaring a witness in a pending cause a perjurer, would be none the less a contempt that it was true. It would tend to obstruct the administration of justice..... What is true with reference to a jury is true also with reference to a court. .... Judges generally, perhaps, are less apprehensive that publications impugning their own reasoning or motives will interfere with their administration of the law. But if a court regards, as it may, a publication concerning a matter of law pending before it, as tending toward such an interference, it may punish it as in the instances put . . . the propriety and necessity of preventing interference with the course of justice by premature statement, argument or intimidation can hardly be denied.... We have scrutinized the case, but cannot say that it shows an infraction of rights under the Constitution of the United States. .... ${ }^{609}$

Any doubt as to the scope of the decision is removed by the dissent of Mr. Justice Harlan, who flatly declared that "the action of the court below was in violation of the rights of free speech and a free press as guaranteed by the Constitution." "I70 That the decision denied the existence of immunity from summary punishment by virtue of the "free press" guar-

$$
\begin{aligned}
& { }^{167} \text { Bridges v. California, 314 U.S. 252, 267-68 (I94I). } \\
& { }^{168} \text { Patterson v. Colorado, } 205 \text { U.S. 454, 457-58 (1907). } \\
& { }^{66} \text { Ibid., at 462-63. }
\end{aligned}
$$


antee has hitherto been unquestioned. ${ }^{77}$ And, as the foregoing historical résumé attempts to demonstrate, the Patterson case more closely approximates the late eighteenth century view of the relation between summary power and the First Amendment ${ }^{x / 2}$ than does the present day reading of Madison's generalizations by Mr. Justice Black. ${ }^{x 73}$

His argument that the First Amendment plainly prohibits religious test oaths or restrictions upon assembly-practices then prevalent in England-and that the right of free press was consequently similarly enlarged beyond the then existing English right, ${ }^{174}$ leaves open the scope of the enlargement. If Madison's views faithfully mirror contemporary opinion, the right was extended beyond freedom from prior executive restraints to limit subsequent legislative restraints. But it is even plainer that contemporary construction rejected the view that the guarantee curtailed the summary power over contemptuous publications. It may well be that there is no logical basis for a differentiation between subsequent legislative and judicial restraints. But this is to substitute twentieth century logic for the "environment in which the First Amendment was ratified," 75 upon which Mr. Justice Black purports to rely. Certainly Madison, whose equivocal utterances the majority invoke to recreate that environment, would have been the first to repudiate the substitution of present-day logic for "the sense in which the Constitution was accepted and ratified by the Nation." For, continued Madison, "In that sense alone it is the legitimate Constitution. And if that be not the guide in expounding it, there can be no security for a consistent and stable government, more than for a faithful exercise of its powers." ${ }^{\text {I76 }}$

${ }^{77}$ This case has been cited by Mr. Justice Holmes in Gitlow v. New York, 268 U.S. 652, 666 (1925), and by Mr. Chief Justice Hughes in Near v. Minnesota, 283 U.S. 697, 715 (I93I). Mr. Justice Holmes' qualification in Schenck v. United States, 249 U.S. 47,5 ( (I9I), that the prohibition of an abridgment of free speech is not confined to previous restraints, indicates his attitude towards restraints under repressive laws rather than a departure from his view that the Fourteenth Amendment left the summary power untouched. Counsel for Bridges himself has declared in a more dispassionate atmosphere that "Mr. Justice Holmes for the majority, in dismissing the writ of error, indicated that in any event the constitutional provision did not prevent punishment of publications after they were made." Fraenkel, One Hundred and Fifty Years of the Bill of Rights, 23 Minn. L. Rev. 719, 759 n. 206 (1939). See Vance, op. cit. supra note 100, at 253. Contra: Schofield, op. cit. supra note II6, at I07.

${ }^{172}$ Note Mr. Justice Holmes' citation of Respublica v. Oswald, I Dall. ( $\mathrm{Pa}$. ) *319 ( 7788 ), in the Patterson case.

${ }^{173}$ "It is the importation of meaning, opinion, and intellectual procedure from the alien world of here and now which makes evidence inconclusive, muddles understanding, and shunts inquiry to false leads." Hamilton and Adair, op. cit. supra note ro7, at I04.

${ }^{74}$ Bridges v. California, 314 U.S. 252, 265 (r94I).

${ }_{75}$ Ibid., at 264 .

${ }^{176} \mathrm{~g}$ Madison, op. cit. supra note III, at I9I, 372. 
THE FEDERAL ACT OF I83I

Twenty-three years ago the city of Toledo was engaged in a controversy with the local traction company about a franchise that was shortly to expire. The city passed an ordinance establishing a three-cent fare, to take effect upon expiration of the franchise. The traction company then sought injunctive relief, and the local newspaper, espousing a popular cause, commented unfavorably upon this turn of affairs, and continued thereafter to publish comments and cartoons which were doubtless unflattering to the court. The federal district court held the publishers in contempt; this judgment was affirmed by the Supreme Court in Toledo Newspaper Co.v. United States. ${ }^{177}$ The case hinged on the Act of $18{ }_{31},{ }^{178}$ which had followed on the heels of Judge Peck's acquittal. Prior to the Toledo case, it had long been believed that the act had deprived the inferior courts of summary power over contemptuous publications. ${ }^{779}$ When, therefore, $\mathrm{Mr}$. Chief Justice White declared in I9I8 that the Act of 183 I left the summary jurisdiction untouched, the decision appeared to its critics to nullify the express will of the American people. ${ }^{x 0}$ Unruffled by this criticism, the Supreme Court continued in subsequent decisions to adhere to the doctrine of the Toledo case. ${ }^{\text {xix }}$ The sanction thus given to the example set by state courts during the second half of the nineteenth century in rendering largely nugatory state statutes patterned after the Act of $183^{I^{182}}$ gave the law a deceptive air of immutability. ${ }^{\mathrm{x} 3}$ The Toledo case was overruled at the last term of court in Nye v. United States. ${ }^{\mathrm{x} 4}$

The unsuspecting medium of history was an illiterate old man who had brought a wrongful-death action in a federal district court. He had been plied with liquor by a relative of the defendant and induced to abandon the suit. Thereupon the district court, located about one hundred miles

${ }_{77} 247$ U.S. 402 (I9r8).

${ }^{178} 4$ Stat. $487(1856)$. The present form of this statute is found in I8 U.S.C.A. $\$ 24 I$ (1927); 28 U.S.C.A. $\$ 385$ ( $\mathrm{r}_{928)}$.

179 See notes $209,220,22 \mathrm{r}$ infra.

${ }^{180}$ Nelles and King, op. cit. supra note 16 , at 533, 54I, 543; cf. Frankfurter and Landis, op. cit. supra note 5 , at 1037, 1058 .

${ }^{28 x}$ Craig v. Hecht, 263 U.S. 255 (1923); Cooke v. United States, 267 U.S. 517 (I925); Sinclair v. United States, 279 U.S. 749 (I929).

${ }^{282}$ Nelles and King, op. cit. supra note 16 , at 533, 537, and cases cited therein.

${ }^{18} 8_{3}$ Thus Nelles and King dolefully remarked that "it might be vain to hope that a long stream of adjudication would reverse its course and flow back up-hill on news that its source was a poisoned spring." Nelles and King, op. cit. supra note 16 , at 4 or.

${ }^{184} 3$ I $_{3}$ U.S. 33 (I94I). 
from the scene of these events, held the relative in contempt for obstructing the administration of justice. The jurisdiction of the district court to proceed summarily if the contempt was in fact criminal was not challenged by the petitioner in the Supreme Court. But the Government, sensing that the specter of contempt by publication lurked behind these drab facts, conceded that the summary power had been curtailed by the Act of I83I, and urged merely that the act was not intended to limit jurisdiction over out-of-court contempts which, as in the case of Nye, actually obstructed the administration of justice. ${ }^{185}$ The majority of the Court, speaking by Mr. Justice Douglas, found the contemnor's conduct "highly reprehensible," ${ }^{86}$ but held that the district court could not proceed summarily because the summary power, since the Act of $183 \mathrm{r}$, extends to no out-of-court contempt which is not "so near" the presence of the court "as to be disrupting to quiet and order." 887 The minority, in an opinion by Mr. Justice Stone, concurred in by Mr. Chief Justice Hughes and Mr. Justice Roberts, agreed that the Act of I83I curtailed the contempt pow$\mathrm{er}^{188}$ thus joining in the erasure of Mr. Chief Justice White's amazing

${ }^{885}$ Brief for the United States 36,39 (No. 558, Oct. r940).

${ }^{286}$ Nye v. United States, 313 U.S. 33,52 (I94I).

${ }^{287}$ In dissenting, Mr. Justice Stone stated that the majority opinion "implicitly holds that no contempt is summarily punishable unless it is either in the presence of the court or is some kind of physical interference with or disturbance of its good order. ...." Ibid., at 54. This seems a fair statement of the majority's position.

Among the issues presented was whether a criminal or civil contempt was involved. The rule to show cause had issued on the motion of counsel for the plaintiff in a civil suit; the Government was first joined on appeal by the clerk of the circuit court of appeals, and participated actively for the first time in the Supreme Court. Applying familiar criteria, the Supreme Court decided that the contempt was criminal. Application of such criteria in the lower courts has proven most unsatisfactory, and the Circuit Court of Appeals for the Second Circuit finally revolted at scanning records with the "object of catching at straws, which lead us first one way and then another, and in the end force us to guess about a matter which could so easily be set right at the beginning." In re Guzzardi, 74 F. (2d) 67I, 673 (C.C.A. 2d I935). Where a court of such distinction must guess, a respondent may understandably first learn on appeal that he was tried below on a criminal charge.

The potential severity and stigma of a criminal sentence require that a defendant be apprised at the outset that he is facing criminal charges. He can then invoke the presumption of innocence, require proof beyond a reasonable doubt, refuse to testify without risking unfavorable comment, and invoke certain defenses, among them a more favorable statute of limitations, and the like. Cf. Civil and Criminal Contempt of Court, 46 Yale L. J. 326 (1936). Under the rule advanced by Judge Learned Hand in McCann v. New York Stock Exchange, 8o F. (2d) $2 \times 1$ (C.C.A. 2d r935), a criminal contempt is either prosecuted by the district attorney or by another attorney directed by the court to prosecute criminally under a written order served on respondent. The fairness of this procedure needs no emphasis. And it will be speedily established when a failure to follow it is attended by reversal on appeal.

${ }^{188}$ Nye v. United States, 313 U.S. 33, 53 (194I). 
dictum that the act had "imposed no limitations not already existing,")899 but denied that the limitation extended to such out-of-court behavior as was present in the Nye case.

The Nye decision was rested almost exclusively on the history of the $P e c k$ case and the structure of the statute. The Peck case, however, turned on considerations of free speech not present in the $N y e$ case; it is therefore proposed to ascertain the bearing of the Peck proceedings on both publication and non-publication cases, to discuss contemporaneous construction of the Act of $183 \mathrm{I}$, and to consider factors of policy that may influence decision.

Although the general references to free press by the Peck prosecutors shed little light on the intention of the framers of the First Amendment forty years earlier, they are obviously relevant to the statute enacted immediately upon Peck's acquittal. Throughout the hearings the Managers hammered home the need for enforcing judicial responsibility by means of unfettered criticism. ${ }^{\text {90 }}$ As Wickliffe, one of the Managers for the House, put it:

We have been laboring under a most fatal delusion upon the subject of our constitutional rights and guarantees, if we are to be told by this high tribunal, that there is one department of our Government, the Judiciary, exempt from free, open and public investigation; one department which can shield itself from responsibility to public opinion by this impenetrable armor, the power to punish for contempts. ${ }^{x g}$

To countenance such judicial insulation would, in the words of Buchanan, result in the erection of "one of the most formidable engines of oppression that was ever set up in a free state." ${ }^{\text {'192 }}$ And as if to give effect to these sentiments forthwith, Congress immediately after the acquittal declared in the Act of 183 I that the contempt power:

Shall not be construed to extend to any cases except the misbehavior of any person or persons in the presence of said courts, or so near thereto as to obstruct the administration of justice, the misbehavior of any of the officers of the said courts in their official transactions, and the disobedience or resistance by any officer of the said courts, party, juror, witness, or any person or persons, to any lawful writ, process, order, rule, decree, or command of the said courts. ${ }^{.93}$

Were the remarks about free speech the sole background of the act, it should properly be construed to deprive the lower federal courts of summary power over all out-of-court criticism of the judiciary. But the

${ }^{889}$ Frankfurter and Landis, op. cit. supra note 5, at I029-30; cf. Ex parte Wall, I07 U.S. 265,302 (1882).

${ }^{190}$ Stansbury, op. cit. supra note 126 , at 92, 297, 426 .

${ }^{191}$ Ibid., at 314. $\quad{ }^{192}$ Ibid., at 437 .

${ }^{293} 4$ Stat. 487 ( 1856 ), 28 U.S.C.A. $\$ 385$ (r928) (italics added). 
Managers time and again conceded the existence of the power over contemptuous publications in pending cases. ${ }^{194}$ It is equally plain that the Managers had no thought of striking down summary control over other out-of-court contempts. True, Spencer, Buchanan and Storrs referred during the proceedings to contempts committed in the face of the court or its immediate precincts by tumultuous conduct and the like. ${ }^{195}$ But these references were illustrative rather than restrictive. In closing the case Buchanan had posed the issue in terms of an absence of power "to punish in a summary manner, as contempts, publications reflecting on the court. ...."196 And though Storrs put the example of the assault upon a judge who was entering the courthouse, he went on to say: "It was as much a contempt and a direct obstruction to the administration of justice as to have kept a juror or witness away by force. . ..."'r97 Storrs had earlier stated in discussing a paragraph of Blackstone that:

In a note to this very paragraph Chitty has put the case, by way of illustration, of attempting to influence a jury. .... So, said Mr. Storrs, he might add . . . offering to bribe a judge; writing him a threatening letter relating to a cause; assaulting a judge on his way to the courthouse.... libelling the parties in the cause in reference to the merits.... . All these contempts show that gross want of respect to courts of justice and their proceedings, without which their legal authority and moral weight would both be lost and the courts of justice made a mere mockery. ${ }^{x}$

In a similar vein, Wickliffe enumerated, among other contempts, "attempts to bribe the witnesses or jurors in a cause, all attempts to prevent an attorney or officer of the court from the discharge of his duty as such. ...."

These statements, conjoined with the concessions as to publications in pending cases, make indisputable an intention to conserve the familiar summary jurisdiction except for publications in non-pending cases. All this may of course be dismissed as the prosecutors' astute attempt so to narrow the issue as to avoid making the impeachment turn on the need for a radical overhauling of the entire contempt power. It is precisely this possibility-that we are confronted with advocacy, with the heated partisanship revealed by resort to impeachment for what was at worst an error of judgment - that suggests it is a mistake to regard the proceedings

194 See note 162 supra; cf. Bridges v. California, 3 I4 U.S. 252,287 n. 3 (I94I).

${ }^{295}$ Stansbury, op. cit. supra note $\mathrm{I} 26$, at 29r, 399, 439; cf. Nelles and King, op. cit. supra note 16 , at 530 .

${ }^{296}$ Stansbury, op. cit. supra note I26, at 434 (italics added). 197 Tbid., at 399.

${ }^{198}$ Ibid., at 397 . Compare Storrs's reaffirmation of his early position that out-of-court bribery was a contempt. Ibid., at 403 .

199 Ibid., at 313. 
as evidence of legislative deliberations, i.e., legislative history. But if the proceedings are invoked as legislative history, those portions which are presently unpalatable cannot be dismissed as mere evidence of forensic skill. So much for the gleanings of legislative intention from the impeachment proceedings.

The actual legislative proceedings contribute only one important fact. In its original form as introduced by Buchanan, the Act of 183 I contained but one section, ${ }^{200}$ the section heretofore considered, limiting the contempt power. Though the bill was enacted in the rush at the end of the session, ${ }^{20 r}$ the Senate yet found time to add a second section punishing by fine and imprisonment after conviction attempts "corruptly, or by threats or force" to influence jurors, witnesses, and officers of the court, or to obstruct the administration of justice. ${ }^{202}$ The Senate, Nelles argues, would scarcely have stopped in the rush of a closing session to add a merely cumulative remedy; the more reasonable purpose was to cover matters not covered by Section I, such as corrupt, out-of-court overtures to jurors and the like. ${ }^{203}$ This was the construction adopted by Justice Baldwin on circuit shortly after passage of the Act of $183 \mathrm{I}$, and on this construction the Nye case to some extent rests. ${ }^{204}$

But the face of Section 2 raises a doubt whether it covers the out-of-

${ }^{200}$ Nelles and King, op. cit. supra note 16 , at 53 I n. 27. ${ }^{201}$ Tbid., at 528.

${ }^{202}$ Ibid., at $53 \mathrm{I} \mathrm{n.} \mathrm{24.} \mathrm{Section} 2$ provides: "That if any person or persons shall, corruptly, or by threats or force, endeavour to influence, intimidate, or impede any juror, witness, or officer, in any court of the United States, in the discharge of his duty, or shall, corruptly, or by threats or force, obstruct, or impede, or endea vour to obstruct or impede, the due administration of justice therein, every person or persons, so offending, shall be liable to prosecution therefor, by indictment. ...." 4 Stat. $488\left(185^{6}\right)$. An amended version of this statute is still in effect. 18 U.S.C.A. $\$ 24 \mathrm{r}$ (1927).

${ }^{203}$ Nelles and King, op. cit. supra note 16 , at 53 I. Some confirmation for the position that the two sections are mutually exclusive is perhaps to be found in the commentary of the New York revisers on the scope of the parallel indictment section in the structurally similar New York Act of 1829 which was possibly called to the attention of Congress. Judge Spencer, a manager in the impeachment proceeding, was the father of one of the revisers. Ibid., at 4 I 6 , 42I $\mathrm{n}$. IIO, 527. In discussing that portion of the New York act, the revisers said: "In the fourth part, many of the offenses which are now punished as contempts, and which are omitted in the preceding section, will be included among misdemeanors. It cannot be necessary at this day, to urge any reason for substituting the trial by jury in all possible cases, instead of a trial by an offended tribunal." Nelles and King, op. cit. supra note 16 , at $421-22 \mathrm{n}$. II2. The federal, New York and Pennsylvania acts are set out in parallel columns, ibid., at 528-29. It is curious that Congress employed the ambiguous phrase "misbehaviour .... so near [the presence of the courts] .... as to obstruct the administration of justice," if the unequivocal New York phrase "any breach of the peace, noise or other disturbance, directly tending to interrupt its proceedings," was before it.

${ }^{204}$ Ex parte Poulson, Fed. Cas. No. Ix,350 (C.C. Pa. I835); see Nye v. United States $3^{1} 3$ U.S. 33, at 49-50 (I94I); Coll v. United States, 8 F. (2d) 20, 22 (C.C.A. Ist I925). 
court contempts allegedly not embraced by Section í. For example, unless contemptuous publications, assuming them to be withdrawn from Section I, constitute an attempt to obstruct justice by "threats," they must be "corrupt" attempts to be comprehended in Section 2. The term "corrupt," however, ordinarily connotes "bribery," suggested by its use in connection with jury-tampering and the like in the first clause of Section 2. A contemptuous publication will not normally be corrupt in this sense, nor, to take a broader definition, will it be "depraved or debased" if it merely expresses honest indignation, although such criticism might be a common law contempt. To this extent, therefore, Section 2 would not cover matters withdrawn from Section $x$. Then too, Section $I$, responding to the desire of the Managers to curb summary control of criticism while preserving some of the common law contempt power over court officers, ${ }^{206}$ patently extends to all out-of-court misconduct by such officers since it penalizes their misbehavior "in their official transactions." ${ }_{207}$ An exclusory construction of Section 2 with reference to this clause of Section I would appear strained. This branch of the argument based on the structure of the statute does not therefore appreciably advance the case for limitation of all out-of-court contempts. There remains the argument that "so near thereto," read in juxtaposition to "presence,"

${ }^{205}$ See Black, Law Dictionary (1933); Murray, New English Dictionary (rg28). For citatations to cases, see zo C.J.S. 239; Words and Phrases (perm. ed.). If the word "corruptly" is not given some such connotation, any attempt to "influence" a juror or "impede" the administration of justice will be penalized; and it follows that the entire adverbial phrase "corruptly, or by threats or force" will be reduced to surplusage, the very result rejected under $\S \mathrm{I}$ in the Nye case with respect to the phrase "so near thereto." Page 000 infra. But see Bosselman v. United States, 239 Fed. 82 (C.C.A. 2d 19I7).

${ }^{306}$ In his memorial to the House, Judge Peck had called attention to the broad power of a court over its officers. Stansbury, op. cit. supra note $x 26$, at 42 . This power rests on almost immemorial usage. See Fox, op. cit. supra note 32, at 249 "officer." One of the earliest cases, that of John de Northampton ( 1344 ) involved the summary punishment of an attorney who had written a letter reflecting on the court. 3 Select Cases in the King's Bench (Edw. I), 58 Seld. Soc. Ixxxiii, cxxxiii-iv (I939), quoted also in Reports of the Select Committee of the House of Commons appointed to consider Sir Francis Burdett's Case, 8 How. St. Tr. I4, $4 \mathrm{I}$ (18I0). Coke cites the case as a contempt, Co. Third Inst. * ${ }^{\prime} 74$, as does Holdsworth, 3 Holdsworth, op. cit. supra note 35, at 390. But see Fox, op. cit. supra note 32, at 24; Fox, op. cit. supra note $4 \mathrm{I}$, at 269 . In 1588 Chancery ordered that an attorney be committed for contemptuous speeches against the Lord Chancellor. Brokas v. Savage, reported in Monro, Acta Cancellariae (1847). See also Ex parte Ingles (I740), Sanders, Chan. Ord. 552 (1845) (solicitor committed for libel); Fox, op. cit. supra note 32, at ro2. The Managers in the Peck impeachment rejected a curb on an attorney's right to criticize the court, but they explicitly recognized the summary jurisdiction over attorneys acting "in the execution of their offices." Stansbury, op. cit. supra note $\mathrm{I} 26$, at $9 \mathrm{I}, 376,406$. The act of $\mathrm{I} 83 \mathrm{I}$ was practically framed in those terms; see Ex parte Wall, 107 U.S. 265,273 (1882).

${ }^{207}$ (Italics added.) Cf. Ex parte Bradley, 7 Wall. 364, 374 (1868). 
suggests physical proximity rather than causal relation. ${ }^{208}$ It does seem that the phrase should be read in this sense; otherwise it is practically reduced to surplusage, since any obstruction however remote becomes an "obstruction to the administration of justice."

Contemporaneous construction, except for expressions that the summary power over contemptuous publications was curtailed, ends with the above-mentioned decision of Mr. Justice Baldwin. ${ }^{209}$ There is little in Ex parte Robinson, ${ }^{2 \mathrm{xO}}$ decided in 1873 , to support the assertion that the "Supreme Court unequivocally confirmed" Mr. Justice Baldwin's construction. ${ }^{21 x}$ In the Robinson case the district court disbarred an attorney for a disrespectful refusal to answer in open court, and the Supreme Court held the disbarment improper. In passing, the Court, describing the Act of $\mathrm{r} 83 \mathrm{I}$ in hasty shorthand, said:

The power of these courts in the punishments of contempts can only be exercised to insure order and decorum in their presence, to secure faithfulness on the part of their officers in their official transactions, and to enforce obedience to their lawful orders, judgments, and processes. ${ }^{2 x}$

This obviously incomplete description which makes no mention of contempts "so near" the presence of the court sheds uncertain light on the scope of that phrase.

The question whether the Act of 183 I limited the summary power to tumultuous disturbances and the like was first presented to the Supreme Court in Savin, Petitioner. ${ }^{213}$ The Savin case is cited by both the majority and the minority of the Supreme Court in the Nye case for confirmation of opposing positions, ${ }^{2 \mathrm{~T}}$ which suggests that it is not an unequivocal authority for either. Savin had attempted to bribe a witness in a pending case,

${ }^{208}$ Nye v. United States, 3 I $_{3}$ U.S. 33,49 (I94I); Nelles and King, op. cit. supra note I6, at 530 .

${ }^{209}$ Ex parte Poulson, Fed. Cas. No. II,350, at I208 (C.C. Pa. 1835); see the remarks of Justice Baldwin in United States v. Holmes, Fed. Cas. No. 15,383 , at 363 (C.C. Pa. I842). But Justice Baldwin's contemporaries appear to regard the Act of $I 8_{3} I$ as a limitation upon libels alone. Thus Buchanan said on the floor of Congress on March 2, I8 36 : "A few days after the acquittal of this Judge [Peck], the Senate.... passed a bill .... under which no Federal Judge will ever again dare to punish a libel as a contempt." 3 Moore, Works of James Buchanan $r_{3}$ (xgo8). Chancellor Kent declared that "The act of Congress .... prohibits all interference by attachment and summary punishment for contempts committed out of the presence of the court, by libels upon the court and the parties. ...." I Kent, Commentaries 300 n. d ( 3 d ed. 1836$)$.

${ }^{270}$ و Wall. (U.S.) 505 ( 1873 ).

$2 x$ Nelles and King, op. cit. supra note 16 , at 532 n. 28.

${ }_{212}$ Ex parte Robinson, I9 Wall. (U.S.) 505, 510-II (I873); see the dissent of Mr. Justice Field in Ex parte Wall, xo7 U.S. 265, 302-3 (I882).

${ }_{213}$ I3I U.S. 267 (I889). 214 Nye v. United States, 313 U.S. I3, 52, 55 (I94I). 
the acts occurring in a witness room not seven feet from, and in the hallway immediately adjoining, the courtroom. The Court recognized that there may be misbehavior "in the vicinity of the building in which the court is held, which, on account of its disorderly character, would actually interrupt the court, being in session, in the conduct of its business, and consequently obstruct the administration of justice."215 But the Court found it unnecessary to decide whether the phrase "so near thereto" was limited to such cases, ${ }^{216}$ basing its decision on an expanded concept of the presence of the court: "the court, at least when in session, is present in every part of the place set apart for its own use, and for the use of its officers, jurors and witnesses; and misbehavior anywhere in such place is misbehavior in the presence of the court."217 Whereupon some of the lower federal courts, apparently unaware that this interpretation of "presence" had been rested on the time-worn notion that judicial precincts were hallowed, ${ }^{218}$ reasoned that if quiet bribery on the threshold of the courthouse, i.e., "in the presence" of the court, were a contempt, then it would be equally contemptuous to do the same thing "so near thereto," e.g., "on the street opposite the court building, or four blocks away." Thus resulted the expansion of the phrase "so near thereto," 220 though

215 Savin, Petitioner, 13I U.S. 267, 276 (1889).

${ }^{216} \mathrm{Ibid}$., at 278.

217 Ibid., at 277 .

${ }^{218}$ There was early common law authority for a construction of "in the presence" extending to the precincts of the court. See Fox, op. cit. supra note 72, at 244. But the Court relied instead on Bacon's statement that "The place of justice is an hallowed place; and therefore not only the bench but the footpace and precincts and purprise thereof ought to be preserved against scandal and corruption." Savin, Petitioner, I3I U.S. 267, 277 (I889).

${ }^{2 x 9}$ In re Brule, 7 I Fed. 943, 948 (D.C. Nev. I895); United States v. Huff, 206 Fed. 700,705 (D.C. Ga. Igr3) (letter delivered to judge at home). Compare Mr. Justice Stone's dissent in Nye v. United States, 3 I3 U.S. 33, 56 (I94r).

${ }^{230}$ One court actually expanded the "presence of the court" to include a juror's place of business half a mile away from the court. McCaully v. United States, 25 App. D.C. 404, 4r3 (I905). In addition to the McCaully case, and the Brule and Huff cases cited in note 219 supra, see In re May, $x$ Fed. 737, 742 (D.C. Mich. I880) (summary punishment of juror); United States v. Anonymous, 2r Fed. 76x, 77 I (C.C. Tenn. x884) (threatening equity examiner on street); Sharon v. Hill, 24 Fed. 726, 732-33 (C.C. Cal. 1885) (misconduct before equity examiner a contempt, but proceeding by indictment instead); Ex parte McLeod, I 20 Fed. I3० (D.C. Ala. I903) (assault upon federal commissioner on the highway); United States v. Zavelo, I77 Fed. 536 (C.C. Ala. I910) (service on out-of-state witness); Kirk v. United States, I92 Fed. 273 (C.C.A. gth IgrI) (attempt to corrupt juror). It is to be emphasized that the May, Anonymous, and Kirk cases recognized the delimitation effected by the Act of $183 \mathrm{I}$ with respect to contempt by publication. In re May, I Fed. 737, 743 (D.C. Mich. 1880); United States v. Anonymous, 2I Fed. 76r, 768 (C.C. Tenn. x884); Kirk v. United States, I92 Fed. 273, 277 (C.C.A. 9th rgrr). Ex parte McLeod lends lip service to this interpretation but finds a specious distinction with respect to publications designed to influence the court in a pending cause. Ex parte McLeod, 120 Fed. 130 I37, (D.C. Ala. 1903). 
there remained courts which took a narrower view. ${ }^{22 I}$ But the remarkable opinion of Mr. Justice Holmes in Patterson v. Colorado furnished scant comfort to proponents of the latter view. ${ }^{222}$

Summarizing the foregoing, the Peck proceedings merely disclose a desire to strike down the summary power over contemptuous publications in non-pending cases, and they seem to indicate an intention to conserve the balance of the common law jurisdiction. The proceedings are of dubious weight as legislative history because highly colored by advocacy. The structure of the statute is inconclusive so far as concerns the inference to be drawn from the separate provisions of Sections I and 2, but the need for giving meaning to the phrase "so near thereto" suggests a construction limiting all out-of-court contempts. Such a limitation was adopted in the contemporary construction of Mr. Justice Baldwin.23 As to the other cases, prior to the Toledo case the Supreme Court had recognized that the Act of 183 I effected a curtailment of the contempt power, but it may be fairly stated that the utterances of the Court as to the scope of the curtailment were equivocal. The lower courts, on the other hand, almost unanimously regarded the Act of $183 \mathrm{I}$ as a restriction on the summary power in publication cases, and were about evenly divided as to whether the "so near" phrase was limited to noisy disturbance of orderly proceedings. ${ }^{224}$

It is not a little remarkable that the opinion of Mr. Justice Douglas in the Nye case should earn praise as an example of "consummate technique in concealing policies beneath artful rhetoric." 225 The considerations that prompted him to eschew a discussion of policy in the face of an equivocal

${ }^{22 x}$ Cuyler v. Atlantic \& North Carolina R. Co., I3I Fed. 95 (C.C. N.C. I904), squarely held that the Act of 183 I curtailed the summary power in publication cases; see Morse v. Montana Ore-Purchasing Co., I05 Fed. 337, 347 (C.C. Mont. I900). The Cuyler case, like Ex parte Schulenburg, 25 Fed. 2 Ir, 218 (C.C. Mich. 1885), declared that the power extended only to loud noises or disturbances so near as to interrupt orderly proceedings. Cuyler v. Atlantic \&

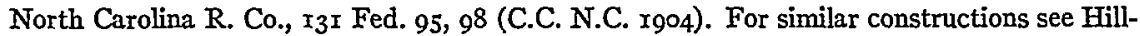
mon v. Mutual Life Ins. Co., 79 Fed. 749 (C.C. Kan. I897) (intimidation of litigant); Atwell v. United States, 162 Fed. 97 (C.C.A. $4^{\text {th }}$ rgo8) (disclosure by juror of grand jury proceedings); Asbestos Shingle, Slate \& Sheathing Co. v. Johns-Manville Co., I89 Fed. 6rI (C.C. N.Y. I9II) (misstatement in advertisement of effect of decision). For a similar result under a "so near" phrase in state statutes, see Commonwealth v. Deskins, 4 Leigh. (Va.) 685 (1834) (concealment to avoid service), Va. Rev. Code (Supp. I833) c. Iog, $\$ 25$; Baldwin v. State, II Ohio St. 68I (I860) (substituting false return in court files), I Ohio Rev. Stat. (Curwen, I853) r22.

. 222 Patterson v. Colorado, 205 U.S. 454 (1907); pages 625-26 supra; Nelles and King, op. cit. supra note 16 , at $539-40$.

${ }^{223}$ But see note 209 supra. 224 See notes 219 and 220 supra.

225 Hamilton and Braden, op. cit. supra note 22, at I319, I363 n. 194. 
statute are obscure. Surely policy is entitled to greatest weight when interstitial legislation is unavoidable. And it is a tenet of the Realist school, to which Mr. Justice Douglas has made distinguished contributions, that legal problems should be articulated in the social terms they really involve, the better to grapple with them. ${ }^{226}$ It is scarcely necessary to remark that no contradiction is involved in accepting the policy factors behind the Bridges decision in a statutory context while rejecting them in the constitutional frame. Policy is an almost inescapable guide to the interpretation of an equivocal statute. It is, however, something else to depart from the historic content of constitutional language in order to give effect to personal prejudices, e.g., to employ the historically procedural due process in order to outlaw minimum wage legislation. We turn now to policy considerations.

Blackstone, though taking a broad view of the contempt jurisdiction, uneasily notes that this method of making the defendant answer upon oath to a criminal charge is not agreeable to the genius of the common law. ${ }^{227}$ Not alone is it disquieting that a man is by his own admission compelled to convict himself, ${ }^{228}$ and that he is tried for a criminal charge without benefit of jury, but also that his prosecutor is at the same time judge and jury in a situation which is frequently charged with personal feeling. ${ }^{22}$ And in the publication cases there is the more potent objection

${ }^{226}$ This was emphasized by Mr. Justice Holmes, copiously quoted in Frank, Law and the Modern Mind 253, 258 (1930); cf. ibid., at 230; see also Holmes, Collected Legal Papers 126, I67 (I920); Nelles, Towards Legal Understanding, 34 Col. L. Rev. Io4r, ro73 (x934). Compare Mr. Justice Douglas' opinion in Textile Mills Securities Corp. v. Com'r, 314 U.S. 326 (194r).

${ }^{237} 4$ Bl. Comm. *287-88; see the remarks of Lord Fitzgerald, concurred in by Lord Bramwell, quoted in Fox, op. cit. supra note 32 , at 42.

${ }_{228}$ Fox, op. cit. supra note 32 , at 70.

${ }^{229} \mathrm{Mr}$. Justice Holmes, dissenting in the Toledo case, said: "when it is considered how contrary it is to our practice and ways of thinking for the same person to be accuser and sole judge in a matter which, if he be sensitive, may involve strong personal feeling, I should expect the power to be limited by the necessities of the case to insure order and decorum in their presence." Toledo Newspaper Co. v. United States, 247 U.S. 402, 423 (I9I8). Mr. Chief Justice Taft later remarked: "The delicacy there is in the judge's deciding whether an attack upon his own judicial action is mere criticism or real obstruction, and the possibility that impulse may incline his view to personal vindication are manifest." Craig v. Hecht, 263 U.S. 255,279 (I923). See note I 7 supra. A significant recognition of the importance of these factors is found in Cooke v. United States, 267 U.S. 517, 539 ( $x_{925}$ ). The Supreme Court suggested that if a judge should be personally attacked he might properly call a fellow judge to act for him; see Cornish $\mathrm{v}$. United States, 299 Fed. 283, 285 (C.C.A. 6th I924); Frankfurter and Landis, op. cit. supra note 5, at ro56; Frankfurter and Greene, The Labor Injunction 190 (1930) (quoting Senator Bacon). It is uncertain whether this is an adequate safeguard, in view of what Nelles and King describe as the tendency of judges to maintain the prestige of their class. Nelles and King, op. cit. supra note 16 , at 547 . 
that a judiciary placed beyond the realm of criticism may become a "formidable engine of oppression." "230 Apart from the check furnished by public opinion, the judiciary is practically free from all restraints. An awakened public opinion not only restricts the growth of arbitrary power, but also exerts a salutary influence on the judicial lag, ${ }^{23 \mathrm{x}}$ as is illustrated by the minimum wage cases. ${ }^{232}$ Or it ultimately produces legislation that overleaps judicial reluctance to adapt the law to a changing economic environment - witness the relation of Workmen's Compensation Acts to intolerable "master and servant" cases. ${ }^{233}$ But free criticism cannot flourish in the in terrorem atmosphere of a pervasive contempt power. Men will not freely speak their minds at the risk of offending a judge who may read criticism as an obstruction of justice. ${ }^{234}$

Against such considerations, it was urged in the Peck proceedings that a judge could not in pursuit of vindication forsake his duties to dance attendance upon grand and petit juries. ${ }^{235}$ Chancellor Kent could not believe that a judge would get a fair hearing from a jury; ${ }^{236}$ Goodhart more recently shrank from the spectacle of a judge undergoing cross-examination. ${ }^{237}$ Others say that ordinary criminal process is too slow to cure the mischief occasioned by published contempts, or that lacking summary punishment an offender may persevere in his misconduct. ${ }^{238}$ Such argu-

${ }^{230}$ Stansbury, op. cit. supra note 126 , at 437 ; Nelles and King, op. cit. supra note 16 , at 403.

${ }^{231}$ Cf. Stone, The Common Law in the United States, 50 Harv. L. Rev. 4, I2 (I937).

${ }^{232}$ Compare Morehead v. New York ex rel. Tipaldo, 298 U.S. 587 (1936), with West Coast Hotel Co., v. Parrish, 300 U.S. 379 (1937).

${ }_{33}$ Laski, Procedure for Constructive Contempt in England, 4r Harv. L. Rev. 1031, 1032 (I928).

234 Ibid., at I033. It is worth noting that Kent and Buchanan appeared, shortly after the passage of the Act of 183 I, to regard it as applicable to all libels on the court. Note 209 supira.

235 Stansbury, op. cit. supra note 126 , at 355,506 .

${ }_{236}$ "If a judge was called a blockhead or a fool, one half of the rude and vulgar jurors of the country might think it a very smart and, possibly, a very true saying. ... . I never would accept judicial office . . . . if $I$ was to be left so naked and defenseless. . ..." Nelles and King, op. cit. supra note I6, at $420 \mathrm{n}$. Io7, quoting Kent's letter.

To this the complete answer is found in Stuart v. People, 3 Scam. (Ill.) ${ }_{395},{ }^{*} 405$ ( 1842 ): "An honest, independent and intelligent court will win its way to public confidence, in spite of newspaper paragraphs, however pointed may be their wit or satire, and its dignity will suffer less by passing them by unnoticed, than by arraigning the perpetrators, trying them in a summary way, and punishing them by the judgment of the offended party." See Laski, op. cit. supra note 233 , at 1040.

237 Goodhart, op. cit. supra note 14 , at 903 .

${ }^{23^{8}}$ Skipworth's and Castro's Case, 9 Q.B. 230, 233 (I873); Respublica v. Oswald, I Dall. (Pa.) * $319, *_{326-27}(\mathrm{I} 788)$. Can it be seriously doubted that the lodging of an information against an offender will cause him to desist, or if he persist, that arrest and bond will act as a deterrent pending trial? 
ments cannot tip the scales against the potentiality of arbitrary power; 239 and arbitrary power is today not a rhetorical flourish but a matter of life or death. There remains the claim that without summary power against contemptuous publications "no court could possibly exist." 240 This socalled "law of necessity," remarks Judge Thomas, is no law at all, for, if it were, "no court could exist without it." ${ }^{4 x}$ No tribunal has been more frequently and harshly criticized than the Supreme Court, yet it has never attempted to stifle criticism by summary punishment. ${ }^{242}$ Respect will not be coerced; it must be won. The true measure of necessity is to be found in the power required to insure orderly procedure, to compel attendance and testimony, and to repel clamorous invasion. ${ }^{243}$ Even this power, as Edward Livingston acutely remarked, need only go so far as to repel, and not to punish. Temporary confinement would sufficiently control contumacious persons, and punishment could be reserved to an impersonal tribunal. ${ }^{244}$ Livingston was a member of the Senate ${ }^{245}$ to which Buchanan presented the argument in his very words; ${ }^{246}$ it was there rejected. But its logic reinforces the social considerations that dictate curtailment of summary power over all contemptuous publications.

In the non-publication cases, the convenience of summary punishment is not opposed by such social pressures as are generated when criticism is inhibited by summary power. And in this field, Livingston's proposal,

${ }^{239}$ Nelles and King enumerate other social interests "paramount to the insulation of the administration of justice": I) judges deal with problems of statesmanship which involve offthe-record factors and which merit thorough discussion; 2) consistent and logical suppression of discussion likely to affect pending cases would mean that some continuing grievances would never be discovered at all; for example, a judicial "dry" bias would escape comment so long as a prohibition law bred new cases; 3 ) newspaper comment is merely one of myriad outside influences that are always at work, and it may serve as a corrective to less desirable influences. Nelles and King, op. cit. supra note 16 , at $55^{\circ}-52$.

${ }^{240}$ Respublica v. Oswald, I Dall. (Pa.) ${ }^{*}{ }_{39},{ }^{*} 326-27$ ( 1788$)$; see Nelles and King, op. cit. supra note 16 , at 537 .

${ }^{24}$ Thomas, The Law of Constructive Contempt 69 (Ig04); People ex rel. Att'y Gen'l v. News-Times Pub. Co., 35 Colo. 253, 430, 84 Pac. 9I2, 968 (Igo6).

242 Thomas, op. cit. supra note $24 \mathrm{I}$, at $67-69$.

${ }^{243}$ Stansbury, op. cit. supra note 126, at 44I; Frankfurter and Landis, op. cit. supra note 5, at 1022; Nelles and King, op. cit. supra note 16 , at 4 18-19.

244 I Livingston, Complete Works 264 et seq. (1873), quoted in Nelles and King, op. cit. supra note I6, at 4I9; Stansbury, op. cit. supra note I26, at 44I et seq.; 3 Wharton, Criminal Procedure $\S \S \mathrm{x} 905$, $1906(1846)$. Judge Spencer for the Managers, and Meredith in behalf of Judge Peck, emphasized that the summary power arises out of the right of self-defense. Stansbury, op. cit. supra note 126 , at 296-329.

${ }_{245}$ Stansbury, op. cit. supra note 126 , at 474 .

${ }^{246} \mathrm{Ibid}$., at $44^{\mathrm{I}-44 ;}$ Nelles and King, op. cit. supra note I6, at 527 . 
though logical, would practically confer immunity on petty offenders. ${ }^{247}$ But in such non-publication cases as may engender judicial resentment, Livingston's analysis buttresses the considerations which suggest that jury trial is to be preferred to summary procedure. Even within the summary jurisdiction outlined in the $N y e$ and Savin cases it may on occasion be judicious to exercise the power of judicial self-limitation. ${ }^{248}$ For this we have the example of English courts which have frequently resorted to $0^{249}$ and possibly prefer jury trial, ${ }^{250}$ be the cases as provoling as that in which a brickbat was thrown at the judge and "narrowly mist." $25 \mathrm{~s}$ Immediate and severe punishment might in such cases seem called for and yet be suspect as the retaliatory reflex of an offended judge. Our deep-rooted instinct for impersonal trial demands that not even the shadow of personal pique should cloud the face of justice. ${ }^{252}$ This ideal must, however, yield when outrageous misconduct that falls within the statutory jurisdiction would otherwise go unpunished. ${ }^{253}$ With the exception, therefore, of cases in which summary procedure is expedientbecause petty offenses will otherwise go unpunished to the detriment of orderly proceedings, the ripe wisdom of Jessel, Master of the Rolls, furnishes a complete guide:

I have myself had on many occasions to consider this jurisdiction, and I have always thought that necessary though it be, it is necessary only in the sense in which extreme measures are sometimes necessary to preserve men's rights, that is, if no other pertinent remedy can be found. Probably that will be discovered after consideration to be the true measure of the exercise of the jurisdiction. ${ }^{254}$

247 "An efficient in terrorem power to maintain order and decorum must have teeth. Peccadilloes too trifling to be worth the bother of sending to another court for prosecution should not for that reason be committed with impunity." Nelles, The Summary Power to Punish for Contempt, 3x Col. L. Rev. 964-66 (I93I).

${ }^{248}$ Cf. Finkelstein, Judicial Self-Limitation, 37 Harv. L. Rev. $33^{8}$ (I924); Berger, Exhaustion of Administrative Remedies, 48 Yale L. J. 981, 994 (I939).

249 Cf. Fox, op. cit. supra note 32, at 24I-42.

${ }^{250}$ Cf. Ex parte Grossman, 267 U.S. 87, xI6 (I925).

${ }^{251}$ Note to Davis's Case, 2 Dyer *I88b, 73 Eng. Rep. R. 4I5-I6 (I63I).

252 See Sharon v. Hill, 24 Fed. 726,733 (C.C. Cal. 1885 ); cf. note 229 supra.

${ }_{253} \mathrm{Cf}$. United States v. Pendergast, 39 F. Supp. I89 (Mo. I94 X). It is not intended to express an opinion as to whether the misconduct in the Pendergast case took place in the presence of the court; see Sharon v. Hill, 24 Fed. 726, 733 (C.C. Cal. I885); In re May, I Fed. 737, 742-43 (D.C. Mich. I880); Nelles, The Summary Power to Punish for Contempt, 3 I Col. L. Rev. 956, 966 (I93I).

254 In re Clements v. Erlanger, 46 L.J. (Ch.) 375,383 (I877); cf. Frankfurter and Landis, op. cit. supra note 5 , at 1051. This discussion has been confined to such contempts as constitute an obstruction to the administration of justice. But the need for judicial self-limitation is no less present in the field of disobedience of injunctive orders issued in labor controversies. Legislative policy has been indicated by repeated limitation of injunctive interference in labor 
Not long ago Mr. Justice Jackson, then Solicitor General, published an article entitled "Back to the Constitution," 255 in which he compared the recent emergence of the constitutional text from beneath a laissez faire gloss to the rediscovery of an Old Master after the retouching brushwork of succeeding generations has been removed. Despite the excellence of the rediscovered Constitution, it was yet obliquely intimated that the document was to be refurbished with a more fitting gloss, ${ }^{256}$ for in the article was quoted Marshall's famous dictum that the Constitution is "intended to endure for ages to come, and consequently to be adapted to the various crises of human affairs." ${ }_{257}$ Perhaps adaptation of the Constitution by the Court to the needs of a rapidly changing society is indeed a law of constitutional survival. And now that the first fine rapture of debunking has passed, we can perceive that in its early stages the extension of substantive due process was on the whole an adaptation to the needs of an expanding industrial society. ${ }^{258}$ It was the refusal of the Court over a long period to make the readaptation necessitated by our changing economic world, to relax the bonds of a once beneficent individualism, that proved crucial. 259

The costs of this wilfulness in terms of a generation of sweated labor and unchecked industrial piracy should remind us that a Court which can read a beneficial power into the Constitution today can read out cher-

disputes, and by the provision of the Clayton Act for jury trial in the case of contempts which also constitute criminal offenses. 38 Stat. 738 ( $\left(\right.$ gr $\left._{4}\right)$ ), 28 U.S.C.A. $\$ 387$ (rg4o); see Frankfurter and Landis, op. cit. supra note 5 , at Io38-4r, ro53.

${ }^{25 s} 25$ A.B.A.J. 745 (1939).

${ }^{256} \mathrm{Cf}$. Hamilton and Adair, op. cit. supra note ro7, at 194.

257 Jackson, Back to the Constitution, 25 A.B.A.J. 745,748 (I939).

${ }_{25} 8$ "Due process was fashioned from the most respectable ideological stuff of the later nineteenth century. The ideas out of which it was shaped were in full accord with the dominant thought of the age. .... In philosophy it was individualism, in government laissez faire, in economics the natural law of supply and demand, in law the freedom of contract. The system of thought had possessed every other discipline; it had in many a domain reshaped the law to its teachings. . . . An impact that had been irresistible elsewhere should surely have won its way into constitutional law." Hamilton, The Path of Due Process of Law, in Read, The Constitution Reconsidered 167,189 ( 1938 ). Corwin calls the extension of due process "an achievement which the American democracy tolerated, even welcomed, in the name of prosperity." Corwin, op. cit. supra note I, at 9I, IOI. See Borchard, The Supreme Court and Private Rights, 47 Yale L. J. 1051, 1054, 1057, 1058 (1938).

259 Borchard, op. cit. supra note 258, at 1055; Hamilton and Adair, op. cit. supra note ro7, at 193 . 
ished rights tomorrow. ${ }^{260}$ Possibly the menace of arbitrary power should lead us with Madison and Taney to prefer a Constitution carrying the meaning and intent it had for the framers. ${ }^{26 x}$ This is not the place to evaluate the divergent theories of Madison and Marshall, ${ }^{262}$ though a reappraisal of those theories in the light both of liberal ascendancy on the Court and the sharpened conflict between totalitarianism and constitutional authority is needed. Here it may be assumed that adaptation and survival are inseparable. But adaptation to what? To "the dominant political forces of the country as revealed at the ballot box," says Corwin. ${ }^{263}$ Yet an "unadapted" Constitution may be the last refuge of minorities if a national Huey Long comes to power. Such fears must be set aside when the nation seeks to cope with an unprecedented emergency, a "crisis in human affairs." 264 Adaptation may then be imperative, and possibly this is a test of the need for adaptation. But can it be seriously urged that the sporadic exercise of summary power over contemptuous publications provokes such a crisis, particularly when such redoubtable liberals as Mr. Chief Justice Stone and Mr. Justice Frankfurter believe that the Bridges decision imperils rather than rescues civil liberties? ${ }^{265}$ Even advocates of a flexible Constitution recognize that judicial exercise of the vast power of adaptation can be tolerated only when tempered by self-restraint. It is the melancholy lesson of the Bridges case that it is easier to preach self-restraint to the opposition than to practice it oneself. ${ }^{266}$

${ }^{260}$ See McIlwain, Constitutionalism and the Changing World 264, 270 (1939); Hamilton and Braden, op. cit. supra note 22, at 1375 .

26x For the views of Madison, see page 627 supra; for those of Taney, see Scott v. Sandford, I9 How. (U.S.) 393,426 ( 1856 ). Yet in the very same opinion Taney could find substantive due process in the Constitution. Ibid., at $45^{\circ}$. See also the Passenger Cases, 7 How. (U.S.) $*_{28},{ }_{478}$ (1849).

${ }^{262}$ See Corwin, op. cit. supra note $I$, at 7-I5.

${ }_{263}$ Corwin, Court Over Constitution I26 (r938).

${ }^{26} 4$ The attempt to deal with the staggering effects of the depression is an example, though only a scraping of the barnacles from the Constitution was necessary to loose national powers. Compare Hamilton and Adair, op. cit. supra note ro7.

${ }^{265}$ One may differ with the minority's estimate of the perils and yet believe that the existence of such a difference between those who cherish liberal ideals indicates the absence of a crisis.

${ }^{266}$ That lesson is to be found in the dissent of Mr. Justice Frankfurter as well. "We must," he adjures the majority, "be fastidiously careful not to make our private views the measure of constitutional authority." Bridges v. California, 3I4 U.S. 252, 293 (194I); see ibid., at 279. The learning cited by him with respect to non-curtailment of the contempt power by the First and Fourteenth Amendments, page 602 supra, should lead him to reject any limitation on the power. Instead, he agrees that there is a limitation with respect to the cases in which he finds the threat to impartial trial negligible, note ro supra, and calls for self-restraint only in the two cases where, parting from the majority, he finds the threat real. 